\title{
Design Algorithm and Performance Analysis of Conventional and Fuzzy Controller for Maintaining the Cane Level during Sugar Making Process
}

\author{
Yogesh Misra \\ Research Scholar, Mewar University, Chittorgarh, Rajasthan, India \\ E-mail: yogeshmisra@yahoo.com \\ Prof. (Dr.) H R Kamath \\ Director, Malwa Institute of Technology, Indore, Madhya Pradesh, India \\ E-mail: rskamath272@gmail.com
}

\begin{abstract}
The amount of cane fiber carried by cane carrier varies due to non-uniformity of cane supply. The continuous variation of cane in chute during the cane juice extraction inversely affects the cane juice extraction efficiency of mill. This paper deals with the development and performance comparison of conventional controller and fuzzy controller to maintain the cane level in chute during juice extraction. The conventional controller is developed using VHDL language and simulated by using Xilinx ISE 14.5 version. The fuzzy controller is developed and simulated by using fuzzy toolbox of 'MATLAB ${ }^{\circledR}$ version 7.11.0.584 (R2020b).
\end{abstract}

Index Terms - Sugar, Cane, Juice Extraction, Conventional Controller, Fuzzy Controller, VHDL

I. INTRODUCTION
India is second largest sugar producer after Brazil in world. More than $60 \%$ of the world's sugar production is from sugar cane and the balance is from sugar beet [1]. In India 60 million cane farmers and their dependents depend on the cane cultivation [2]. The Indian share in sugar production is gone up in past few decades and in the marketing year $2011-12$ it is $15.07 \%$ of world's total sugar production.

There are 566 sugar factories installed in India with a capital investment of Rs. 500 Billion. The central and state governments collect around Rs. 50 Billion in the form of various taxes. The comparison of sugar production and it's consumption in past five years in India is graphically represented in Fig. 1 [3] [4].

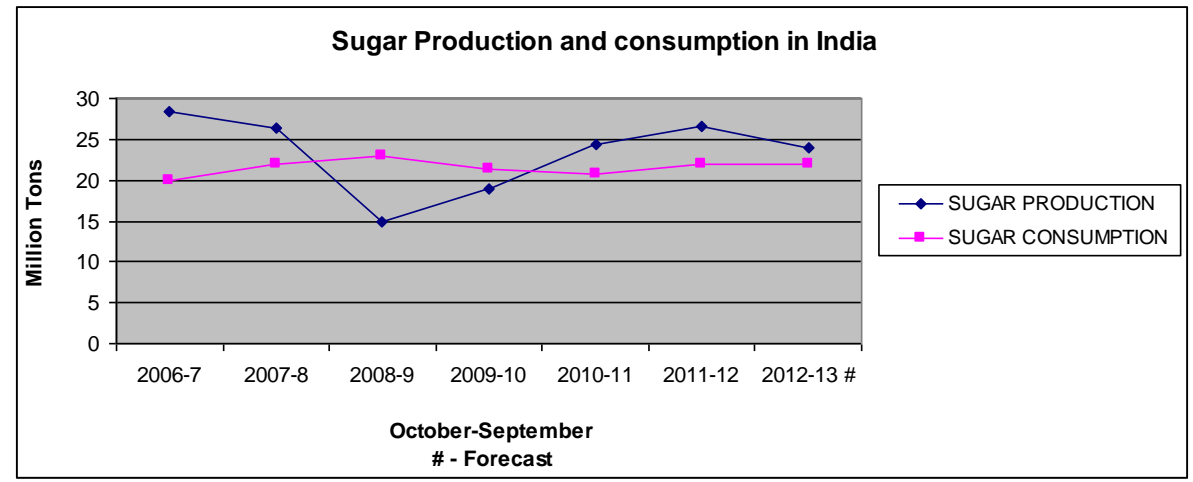

Fig. 1. Sugar Production and Sugar Consumption

During sugar manufacturing the cane billets are converted into cane fiber and this cane fiber is crushed by a series of five to six mills for the extraction of cane juice. The residual of fiber after juice extraction is conveyed to the boiler station where it is used as fuel. The cane juice extracted from the milling train contains impurities and the clarification of the cane juice is the next step. The juice clarification process converts the impurities into a thick paste of mud which settle down in the clarifier vessel while clarified juice overflows the clarifier vessel. The separated mud is used as fertilizers. The thin clarified juice is concentrate to heavy syrup by boiling it from a 
series of evaporators at high vacuum. The heavy syrup contains $65 \%$ of sugar. The heavy syrup, which is also called as mother liquor, is seeded with small sugar crystal and further concentrated by boiling in vacuum pan. This process of crystal growth by adding seed crystal in syrup is called crystallization. The crystallization process is a batch process in which the pans are filled with mother liquor, heated with steam flowing through the pipes inside it and are then emptied for next boiling. The mixture of mother liquor and grown crystals in pan is called as massecuite. After the growth of crystals the massecuite is discharged in receiving tank called crystallizer and pan is ready to receive new mother liquor for new boiling. Sugar crystals are separated from the mother liquor in centrifuges and send for storing. The mother liquor separated from sugar crystals during centrifugal process is called as molasses. The raw sugar from the centrifugal is dried by tumbling through a stream of air in a rotating drum. The dried sugar is then stored and ready to use [5] [6]. During sugar making process the cane juice extraction is effected by the continuous variation of cane in chute.

In this paper we have developed a conventional controller by using VHDL language and a fuzzy controller by using fuzzy logic toolbox of Matlab. The conditioning systems are also developed for raising the level of analog signals generated from load cell and cane level measuring sensor. Finally the performance of the fuzzy controller and conventional controller are analyzed.

\section{IMPORTANT TERMINOLOGY OF MILL}

Two rolls and the chute arrangement used for cane crushing are shown in Fig. 2. It has been investigated that the physical structure of mill effect the feed depth at which maximum crushing rate can be achieved [7].

Means Roll Diameter (D) - A roll with groves is shown in Fig. 2. The diameter of roll when measured from the tip of groves is Do and Dg is the length of groves and D is the average diameter of roll. The mean diameter of roll is given as:

$$
\mathrm{D}=\mathrm{D}_{\mathrm{o}}-\mathrm{D}_{\mathrm{g}}
$$

Where $\mathrm{D}_{\mathrm{o}}=$ Outside Diameter of roll

$\mathrm{D}_{\mathrm{g}}=$ Groove Depth

Work Opening (W) - The opening measured between the two rolls outside diameter is called as nib opening or set opening and represented by Ws. The opening measured between the mean diameters of two rolls is called work opening and is given as:

$$
\mathrm{W}=\mathrm{W}_{\mathrm{s}}+\mathrm{D}_{\mathrm{g}}
$$

Roll Surface Speed (S) - The surface speed of roll $(\mathrm{m} / \mathrm{s})$ is given as:

$$
\mathrm{S}=(\omega \times \mathrm{D}) / 2
$$

Where $\omega$ is the angular velocity of the roll and (3) can also be written as:

$$
\mathrm{S}=(\pi \times \mathrm{D} \times \mathrm{N}) / 60
$$

Where $\mathrm{N}$ is roll shaft speed in rpm

Optimum feed depth $\left(\mathbf{B}_{\mathbf{c}}\right)$ - The thickness of cane blanket at the feed opening of the mill effects the juice extraction from the mill. The optimum feed depth is investigated and found as follows:

$$
\mathrm{B}_{\mathrm{c}}=(\mathrm{W}+\mathrm{D}) / 2
$$

Contact Angle Between pair of Rolls $(\alpha)$ - The contact angle is the angle between the line joining the center of the two rolls and the line joining the center of roll to the point where chute touches the roll. The contact angle is given as:

$$
\operatorname{Cos} \alpha=\left(\mathrm{D}+\mathrm{W}-\mathrm{B}_{\mathrm{c}}\right) / \mathrm{D}
$$

Escribed volume $\left(V_{\mathbf{e}}\right)-$ The escribed volume $\left(\mathrm{m}^{3} / \mathrm{s}\right)$ is the volume of prepared cane passing through the work opening of the mill and is given as:

$$
\mathrm{Ve}=\mathrm{L}_{\mathrm{r}} \times \mathrm{D} \times \mathrm{S}[1+(\mathrm{W} / \mathrm{D})-\operatorname{Cos} \alpha) \operatorname{Cos} \alpha
$$

Where $\mathrm{L}_{\mathrm{r}}$ is roll length

The average speed of cane blanket $\left(\mathrm{S}_{\mathrm{f}}\right)$ at the point where chute touches the rolls is $S \operatorname{Cos} \alpha$. At the entry of chute the volume of cane passing the entry plane is given as:

$$
\mathrm{V}_{\mathrm{e}}=\mathrm{L}_{\mathrm{r}} \times \mathrm{B}_{\mathrm{c}} \times \mathrm{S} \operatorname{Cos} \alpha
$$

$$
\begin{aligned}
& \text { Dimension of chute } \\
& L_{c}=\text { Length }=180 \mathrm{~cm} \\
& W_{c}=B_{c}=\text { Width }=43.5 \mathrm{~cm} \\
& D_{c}=L_{r}=\text { Depth }=183 \mathrm{~cm} \\
& \text { Optimum feed depth }\left(B_{c}\right)=43.5 \mathrm{~cm}
\end{aligned}
$$

\section{The various parameters of mill}

$\mathrm{L}_{\mathrm{r}}=183 \mathrm{~cm}$

$\mathrm{D}=75.5 \mathrm{~cm}$

$\mathrm{W}=11.45 \mathrm{~cm}$

$\mathrm{B}_{\mathrm{c}}=43.5 \mathrm{~cm}$

$\alpha=61^{\circ}$

$\mathrm{S}=16.6 \mathrm{~cm} / \mathrm{s}$

$\mathrm{S}_{\mathrm{f}}=8.07 \mathrm{~cm} / \mathrm{s}$

$\mathrm{P}_{\mathrm{c}}=$ Mass density of prepared cane $=350 \mathrm{Kg} / \mathrm{m}^{3}$

$\mathrm{Q}$ is the mass flow rate of cane through the mill and is given as:

$\mathrm{Q}=\rho \mathrm{cLrDS}[1+(\mathrm{W} / \mathrm{D})-\operatorname{Cos} \alpha) \operatorname{Cos} \alpha]$ (9)

After solving the (9) we get $26.6 \mathrm{Kg} / \mathrm{sec}$ flow rate. With $26.6 \mathrm{Kg} / \mathrm{sec}$ flow rate 2200 tons of cane will be crushed in 24 hours.

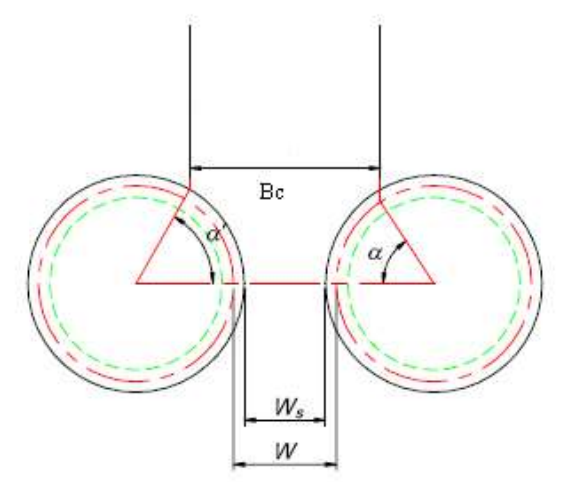

Fig. 2. Two Rolls and Chute Arrangement of a Mill 


\section{CANE JUICE EXTRACTION AND CONTROL AlgORITHM}

Cane juice extraction is very important process of a sugar mill which affects the sugar mill's efficiency. The cane billets received by sugar mill from cane growers are weighted and dumped in cane yard. From the cane yard the cane billets are dumped in the cane carrier with the help of a crane. The cane carrier moves continuously and is responsible for bringing the cane to the factory for sugar production. The cane is first passed through two sets of rotating knives. The first one is called cane knives and it cut the cane into pieces. The second set is called as shredder knives and it prepare the fiber of cane billets. The small fibers are around 1-2 cm. The cane fibers are feed to Donnelly chute and cane juice is extracted by crushing fiber in two or three rolls of the mill [8]. This process is repeated through sets of five/six mills until last mill is reached. Before the crushing of cane fiber in last mill it is immersed in a diluted mixture of final mill cane crushing juice and hot water. The residual cane fiber after the last mill is called bagasse is conveyed to bagasse bin and finally to the boiler station where it is used as fuel [9]

In a sugar mill for optimum juice extraction and better sugar production efficiency the cane level in Donnelly chute is to be maintained constant.

Maintaining the cane level during cane juice extraction is an important task of the operator. Cane fiber is carried by cane carrier and finally dumped in Donnelly chute from where it is crushed by the rollers. The amount of cane fiber carried by cane carrier varies due to nonuniformity of cane supply. If the level of cane fiber falls below the desired level then the speed of cane carrier motor is to be increased and if the level of cane fiber rises above the desired level the speed of cane carrier motor is to be decreased for maintaining the desired level.

In the previous section various parameters are selected for achieving $26.6 \mathrm{Kg} / \mathrm{sec}$ flow rate. The inclined chute allows the movement of fiber down the chute at constant velocity. Fiber is assumed to fail in a similar was to soils. The 'failure ratio' in fiber is the ratio of maximum shear stress to shear strength of fiber. A volume of prepared cane contains fiber, air and juice. When fiber is compressed in a pair of roll then air is expressed until fiber contains only fiber and juice. Any further compression of fiber expresses juice. It has been investigated that failure rate of fiber decreases with the increment of pressure applied on fiber at mill opening but beyond certain value the failure rate starts increasing with the increment of feed pressure.

The failure rate is minimum (0.04) when the feed pressure is $2 \mathrm{kPa}$ [7].

For an open chute pressure due to fiber in chute is given as:

$\mathrm{p}=\rho \mathrm{c}(\operatorname{Sin} \theta-\mu \operatorname{Cos} \theta) \mathrm{L}$

Here, $\theta=$ Chute inclination wrt horizontal

$\mathrm{L}=$ Height of cane in chute.

$\mathrm{P}=2 \mathrm{kPa}=0.02039 \mathrm{Kgf} / \mathrm{cm}^{2}$

$\theta=61^{\circ}$

$\mathrm{Pc}=350 \mathrm{Kg} / \mathrm{m}^{3}=350 \times 10^{-6} \mathrm{Kg} / \mathrm{cm}^{3}$
After solving the (10) we get $90 \mathrm{~cm}$ height of cane in chute. In order to minimize the failure rate of fiber the cane must be maintained at $90 \mathrm{~cm}$ in chute.

A schematic of cane juice extraction from first mill is shown in Fig.3.

The cane fiber is dumped in Donnelly chute of height $180 \mathrm{~cm}$. The Rake Carrier which carries the cane fiber up to Donnelly chute is of length $800 \mathrm{~cm}$, width $150 \mathrm{~cm}$ and its weight is $500 \mathrm{Kg}$. The cane fiber on rake carrier varies from $500 \mathrm{Kg}$ to $1000 \mathrm{Kg}$.

Two sensors are required to sense the cane in rake carrier and height of cane in chute. A load cell is used to sense the load on rake carrier and light sensor is used to measure the height of cane in chute. Depending upon the values of cane in rake carrier and height of cane in chute the speed of rake carrier motor is increased or decreased to maintain cane level at $90 \mathrm{~cm}$.

\section{A. Load Cell signal conditioning circuit}

Load Cell of $1500 \mathrm{Kg}$ capacity, $2 \mathrm{mV} / \mathrm{V}$ and $10 \mathrm{~V}$ excitation is used to measure the weight of cane on rake carrier. If the weight of rake carrier including the weight of cane is $1500 \mathrm{Kg}$ and the excitation voltage used in load cell is $10 \mathrm{~V}$ then the load cell will generate $20 \mathrm{mV}$.

A Signal Conditioning system as shown in Fig.4 is required to lift the level of load cell generated voltage in the range 0 to $2.5 \mathrm{~V}$. Two operational amplifiers are used as signal conditioning. Output of signal conditioning system which is proportional to the load cell output is feed to IC0804 analog to digital converter.

The output of ADC in hexadecimal format is shown in Table 1.

\section{B. Chute Height signal conditioning circuit}

A schematic for sensing the height of cane in chute is shown in Fig.3. A light sensor is placed at $300 \mathrm{~cm}$ height from the base of chute. When the cane is at the base of chute then sensor will generate $20 \mathrm{~mA}$ and when the cane is at $180 \mathrm{~cm}$ height then the sensor will generate $8 \mathrm{~mA}$. The digital output of chute height conditioning system is shown in Table 2.

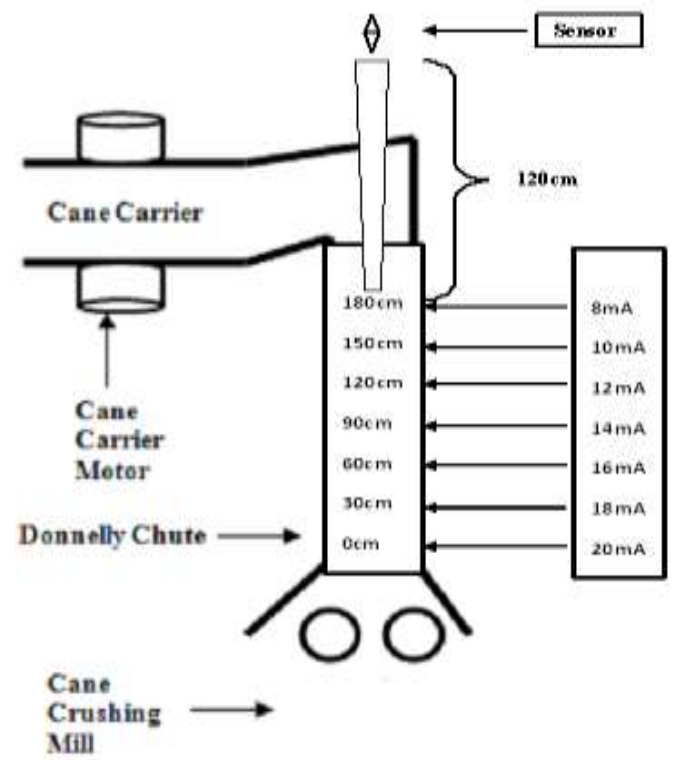

Fig. 3. Cane Juice Extraction from $1^{\text {st }}$ Mill 
Design Algorithm and Performance Analysis of
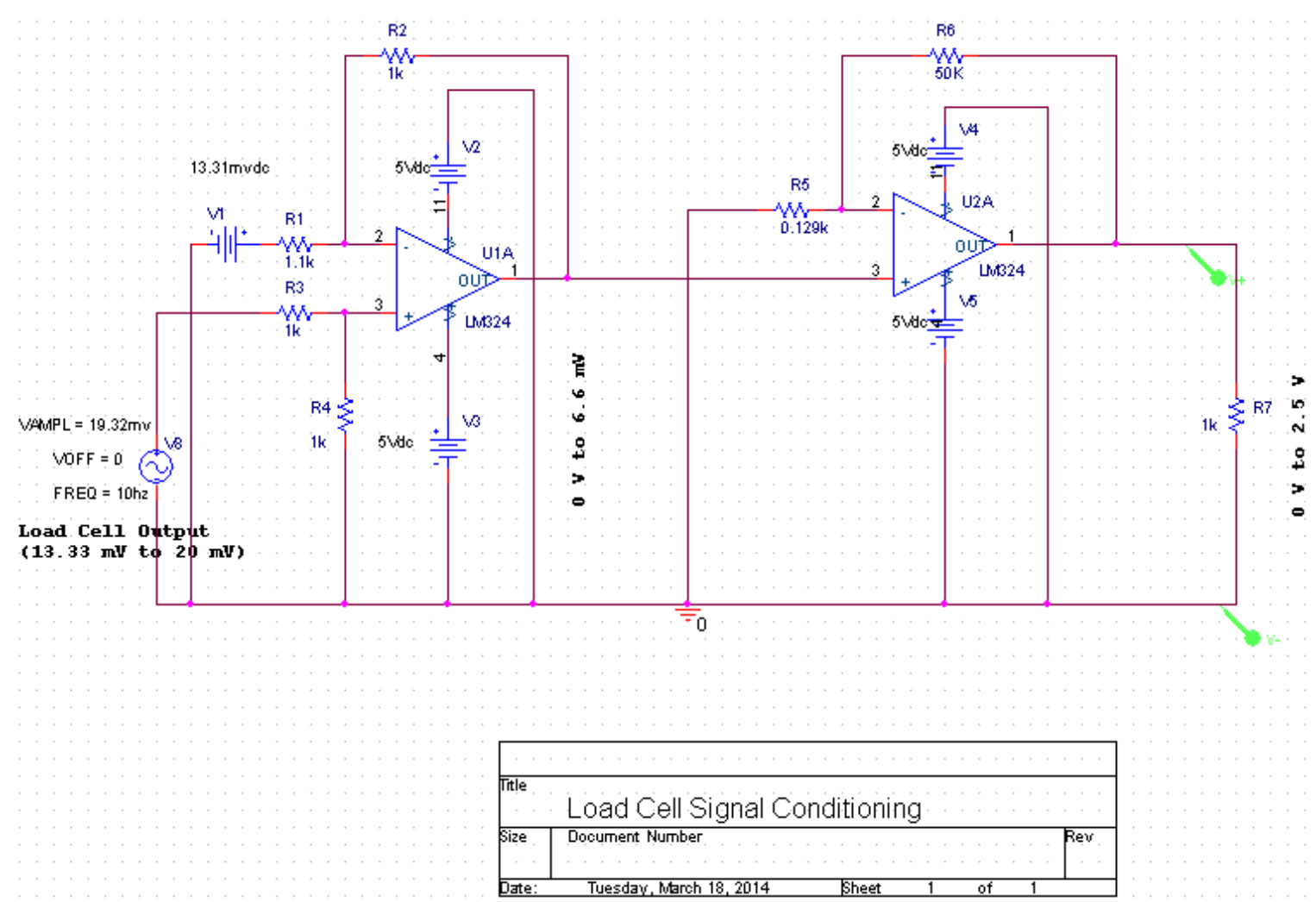

Fig. 4. Signal Conditioning System for Load Cell

Table 1. Digital Output of Load Cell Conditioning System

\begin{tabular}{|c|c|c|c|}
\hline (Carrier + Cane) Weight $(\mathrm{Kg})$ & Output of load cell $(\mathrm{mV})$ & Output of signal conditioning system(V) & Outputof ADC( Hex) \\
\hline 1000 & 13.33 & 0 & $00 \mathrm{H}$ \\
\hline 1050 & 13.99 & 0.261 & $1 \mathrm{BH}$ \\
\hline 1100 & 14.66 & 0.509 & $34 \mathrm{H}$ \\
\hline 1150 & 15.33 & 0.756 & $4 \mathrm{DH}$ \\
\hline 1200 & 15.99 & 1.00 & $66 \mathrm{H}$ \\
\hline 1250 & 16.66 & 1.25 & $80 \mathrm{H}$ \\
\hline 1300 & 17.32 & 1.49 & $99 \mathrm{H}$ \\
\hline 1350 & 17.99 & 1.77 & B5H \\
\hline 1400 & 18.66 & 1.98 & $\mathrm{CBH}$ \\
\hline 1450 & 19.32 & 2.23 & $\mathrm{E} 4 \mathrm{H}$ \\
\hline 1500 & 20.00 & 2.50 & FFH \\
\hline
\end{tabular}

Table 2. Digital Output of Chute Height Measurement Conditioning System

\begin{tabular}{|c|c|c|c|c|}
\hline Cane height $(\mathrm{cm})$ & Ootput of sensor $(\mathrm{mA})$ & Output of signal conditioning system(V) & Output of ADC( Hex) & Inverse of ADC output( Hex) \\
\hline 0 & 20.0 & 2.0 & $\mathrm{CDH}$ & $32 \mathrm{H}$ \\
\hline 30 & 18.0 & 1.8 & $\mathrm{~B} 8 \mathrm{H}$ & $47 \mathrm{H}$ \\
\hline 40 & 17.3 & 1.7 & $\mathrm{~B} 1 \mathrm{H}$ & $4 \mathrm{EH}$ \\
\hline 60 & 16.0 & 1.6 & $\mathrm{~A} 4 \mathrm{H}$ & $5 \mathrm{BH}$ \\
\hline 80 & 14.7 & 1.47 & $96 \mathrm{H}$ & $69 \mathrm{H}$ \\
\hline 90 & 14.0 & 1.4 & $8 \mathrm{FH}$ & $70 \mathrm{H}$ \\
\hline 100 & 13.3 & 1.33 & $88 \mathrm{H}$ & $77 \mathrm{H}$ \\
\hline 120 & 12.0 & 1.2 & $7 \mathrm{BH}$ & $84 \mathrm{H}$ \\
\hline 130 & 11.3 & 1.1 & $74 \mathrm{H}$ & $8 \mathrm{BH}$ \\
\hline 150 & 10.0 & 1.0 & $66 \mathrm{H}$ & $99 \mathrm{H}$ \\
\hline 180 & 8.0 & 0.8 & $52 \mathrm{H}$ & $\mathrm{ADH}$ \\
\hline
\end{tabular}




\section{CONVENTIONAL CONTROLLER DESIGN}

The conventional controller has two inputs to sense the availability of cane in rake carrier and the height if canein chute. Depending upon these two inputs the feed rate of cane in chute will vary. The VHDL [10] algorithm for the development of conventional controller is based on Table 3. VHDL is IEEE standard and widely used languages for describing a digital system [10]. The most important part of VHDL is its technology independency [11] [12].

Behavior Model of the controller is developed and available with the authors. The functionality of the system is verified from the waveform generated by the simulation tool. A simulation run was performed on the Xilinx ISE 14.5 version platform for four different cases of varying cane load and varying cane level and result is shown in Table 6.

Example 1 - The simulated waveform of the system is shown in Fig. 5 which shows the condition when cane height in chute is $60 \mathrm{~cm}$ and cane weight in rake carrier is $550 \mathrm{Kg}$.

The total weight of cane on carrier is $550 \mathrm{Kg}$. According to the design logic for cane weight in the range $550 \mathrm{Kg}$ to $599 \mathrm{Kg}$ the weight of cane on carrier is considered as $0.719 \mathrm{Kg} / \mathrm{cm}$ (this is calculated by considering cane weight as $575 \mathrm{Kg}$ ). According to the design logic the cane flow rate must be enhanced by $10 \%$ for the given condition. Therefore feed rate should be $29.3 \mathrm{Kg} / \mathrm{s}$. To maintain this flow rate rake carrier must run at $(29.3 / 0.719) \mathrm{cm} / \mathrm{s}$ i.e. $40.8 \mathrm{~cm} / \mathrm{s}$.

A wheel is used to move the rake carrier and wheel will run by dc motor. The linear distance covered by the rake carrier wheel is given as:

$$
\mathrm{L}_{\text {rake }}=\left(\mathrm{R}_{\mathrm{rpm}} \times \Pi \times \mathrm{D}_{\text {wheel }}\right) / 60
$$

Where $\mathrm{L}_{\text {rake }}=$ Speed of rake carrier $=40.8 \mathrm{~cm} / \mathrm{s}$

$\mathrm{D}_{\text {wheel }}=$ Diameter of wheel $=10 \mathrm{~cm}$

The speed of wheel in rpm is represented by $\mathrm{W}_{\mathrm{rpm}}$ and given as:

$$
\mathrm{W}_{\mathrm{rpm}}=\left(60 \times \mathrm{L}_{\text {rake }}\right) /\left(\Pi \times \mathrm{D}_{\text {wheel }}\right)
$$

After solving (12) we get 78rpm wheel speed Fig.5.

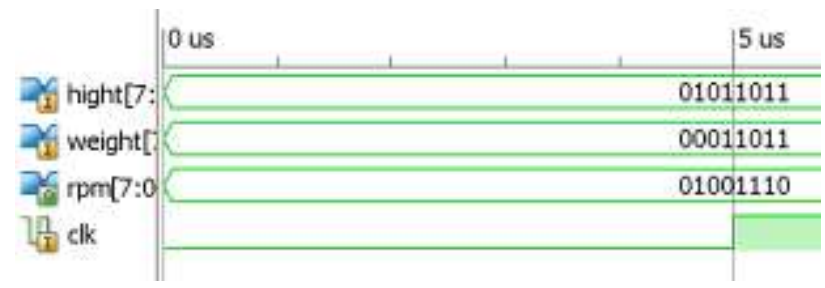

Fig. 5 . Height $=60 \mathrm{~cm}$, Weight $=550 \mathrm{Kg}$ and $R P M=78 \mathrm{RPM}$

Table 3. Conventional Controller Design Algorithm

\begin{tabular}{|c|c|c|c|c|}
\hline 550 to 599 & $+30 \%$ & 34.6 & 48.1 & 92 \\
\hline 600 to 649 & $+30 \%$ & 34.6 & 44.3 & 85 \\
\hline 650 to 699 & $+30 \%$ & 34.6 & 41.0 & 78 \\
\hline 700 to 749 & $+30 \%$ & 34.6 & 38.2 & 73 \\
\hline 750 to 799 & $+30 \%$ & 34.6 & 35.8 & 68 \\
\hline 800 to 849 & $+30 \%$ & 34.6 & 33.6 & 64 \\
\hline 850 to 899 & $+30 \%$ & 34.6 & 31.6 & 60 \\
\hline 900 to 949 & $+30 \%$ & 34.6 & 29.9 & 57 \\
\hline 950 to 1000 & $+30 \%$ & 34.6 & 28.4 & 54 \\
\hline \multicolumn{5}{|c|}{ Cane Level $>=30 \mathrm{~cm}$ and $<60 \mathrm{~cm}(\mathrm{VL})$} \\
\hline 500 to 549 & $+20 \%$ & 31.9 & 48.6 & 93 \\
\hline 550 to 599 & $+20 \%$ & 31.9 & 44.4 & 85 \\
\hline 600 to 649 & $+20 \%$ & 31.9 & 40.8 & 78 \\
\hline 650 to 699 & $+20 \%$ & 31.9 & 37.8 & 72 \\
\hline 700 to 749 & $+20 \%$ & 31.9 & 35.2 & 67 \\
\hline 750 to 799 & $+20 \%$ & 31.9 & 33.0 & 63 \\
\hline 800 to 849 & $+20 \%$ & 31.9 & 30.9 & 59 \\
\hline 850 to 899 & $+20 \%$ & 31.9 & 29.2 & 56 \\
\hline 900 to 949 & $+20 \%$ & 31.9 & 27.6 & 53 \\
\hline 950 to 1000 & $+20 \%$ & 31.9 & 26.2 & 50 \\
\hline \multicolumn{5}{|c|}{ Cane Level $>=60 \mathrm{~cm}$ and $<80 \mathrm{~cm}(\mathrm{~L})$} \\
\hline 500 to 549 & $+10 \%$ & 29.3 & 44.7 & 85 \\
\hline 550 to 599 & $+10 \%$ & 29.3 & 40.8 & 78 \\
\hline 600 to 649 & $+10 \%$ & 29.3 & 37.5 & 72 \\
\hline 650 to 699 & $+10 \%$ & 29.3 & 34.7 & 66 \\
\hline 700 to 749 & $+10 \%$ & 29.3 & 32.3 & 62 \\
\hline 750 to 799 & $+10 \%$ & 29.3 & 30.3 & 58 \\
\hline 800 to 849 & $+10 \%$ & 29.3 & 28.4 & 54 \\
\hline 850 to 899 & $+10 \%$ & 29.3 & 26.8 & 51 \\
\hline 900 to 949 & $+10 \%$ & 29.3 & 25.3 & 48 \\
\hline 950 to 1000 & $+10 \%$ & 29.3 & 24.0 & 46 \\
\hline \multicolumn{5}{|c|}{ Cane Level $>=80 \mathrm{~cm}$ and $<100 \mathrm{~cm}(\mathrm{JR})$} \\
\hline 500 to 549 & $0 \%$ & 26.6 & 40.5 & 77 \\
\hline 550 to 599 & $0 \%$ & 26.6 & 37.0 & 71 \\
\hline 600 to 649 & $0 \%$ & 26.6 & 34.1 & 65 \\
\hline 650 to 699 & $0 \%$ & 26.6 & 31.5 & 60 \\
\hline 700 to 749 & $0 \%$ & 26.6 & 29.4 & 56 \\
\hline 750 to 799 & $0 \%$ & 26.6 & 27.5 & 53 \\
\hline 800 to 849 & $0 \%$ & 26.6 & 25.8 & 49 \\
\hline 850 to 899 & $0 \%$ & 26.6 & 24.3 & 46 \\
\hline $\begin{array}{c}\text { Cane } \\
\text { weight } \\
(\mathrm{Kg})\end{array}$ & $\begin{array}{c}\text { Variation } \\
\text { of Feed } \\
\text { Rate } \\
(\%)\end{array}$ & $\begin{array}{c}\text { Feed } \\
\text { rate in } \\
(\mathrm{Kg} / \mathrm{s})\end{array}$ & $\begin{array}{l}\text { Carrier } \\
\text { Speed in } \\
(\mathrm{cm} / \mathrm{s})\end{array}$ & $\begin{array}{l}\text { Motor } \\
\text { Speed } \\
(\mathrm{rpm})\end{array}$ \\
\hline 900 to 949 & $0 \%$ & 26.6 & 23.0 & 44 \\
\hline 950 to 1000 & $0 \%$ & 26.6 & 21.8 & 42 \\
\hline \multicolumn{5}{|c|}{ Cane Level $>=100 \mathrm{~cm}$ and $<120 \mathrm{~cm}(\mathrm{H})$} \\
\hline 500 to 549 & $-10 \%$ & 23.9 & 36.4 & 70 \\
\hline 550 to 599 & $-10 \%$ & 23.9 & 32.2 & 61 \\
\hline 600 to 649 & $-10 \%$ & 23.9 & 30.6 & 58 \\
\hline 650 to 699 & $-10 \%$ & 23.9 & 28.3 & 54 \\
\hline
\end{tabular}

\begin{tabular}{|c|c|c|c|c|}
\hline $\begin{array}{c}\text { Cane } \\
\text { weight } \\
(\mathrm{Kg})\end{array}$ & $\begin{array}{c}\text { Variation } \\
\text { of Feed } \\
\text { Rate } \\
(\%)\end{array}$ & $\begin{array}{c}\text { Feed rate } \\
\text { in } \\
(\mathrm{Kg} / \mathrm{s})\end{array}$ & $\begin{array}{c}\text { Carrier } \\
\text { Speed in } \\
(\mathrm{cm} / \mathrm{s})\end{array}$ & $\begin{array}{c}\text { Motor } \\
\text { Speed } \\
(\mathrm{rpm})\end{array}$ \\
\hline \multicolumn{4}{|c|}{ Cane Level $>=0 \mathrm{~cm}$ and $<30 \mathrm{~cm}(\mathrm{EL})$} \\
\hline 500 to 549 & $+30 \%$ & 34.6 & 52.7 & 101 \\
\hline
\end{tabular}




\begin{tabular}{|l|l|l|l|l|}
\hline 700 to 749 & $-10 \%$ & 23.9 & 26.4 & 50 \\
\hline 750 to 799 & $-10 \%$ & 23.9 & 24.7 & 47 \\
\hline 800 to 849 & $-10 \%$ & 23.9 & 23.2 & 44 \\
\hline 850 to 899 & $-10 \%$ & 23.9 & 21.8 & 42 \\
\hline 900 to 949 & $-10 \%$ & 23.9 & 20.7 & 40 \\
\hline 950 to 1000 & $-10 \%$ & 23.9 & 19.6 & 37 \\
\hline \multicolumn{5}{|c|}{ Cane Level >=120cm and <150cm (VH) } \\
\hline 500 to 549 & $-20 \%$ & 21.3 & 32.5 & 62 \\
\hline 550 to 599 & $-20 \%$ & 21.3 & 29.6 & 57 \\
\hline 600 to 649 & $-20 \%$ & 21.3 & 27.3 & 52 \\
\hline 650 to 699 & $-20 \%$ & 21.3 & 25.2 & 48 \\
\hline 700 to 749 & $-20 \%$ & 21.3 & 23.5 & 45 \\
\hline 750 to 799 & $-20 \%$ & 21.3 & 22.0 & 42 \\
\hline 800 to 849 & $-20 \%$ & 21.3 & 20.7 & 40 \\
\hline 850 to 899 & $-20 \%$ & 21.3 & 19.5 & 37 \\
\hline 900 to 949 & $-20 \%$ & 21.3 & 18.4 & 35 \\
\hline 950 to 1000 & $-20 \%$ & 21.3 & 17.5 & 33 \\
\hline \multicolumn{5}{|c|}{ Cane Level >= $150 \mathrm{~cm}$ and <=180cm (EH) } \\
\hline 500 to 549 & $-30 \%$ & 18.6 & 28.4 & 54 \\
\hline 550 to 599 & $-30 \%$ & 18.6 & 25.9 & 49 \\
\hline 600 to 649 & $-30 \%$ & 18.6 & 23.8 & 45 \\
\hline 650 to 699 & $-30 \%$ & 18.6 & 22.0 & 42 \\
\hline 700 to 749 & $-30 \%$ & 18.6 & 20.5 & 39 \\
\hline 750 to 799 & $-30 \%$ & 18.6 & 19.2 & 37 \\
\hline 800 to 849 & $-30 \%$ & 18.6 & 18.0 & 34 \\
\hline 850 to 899 & $-30 \%$ & 18.6 & 17.0 & 32 \\
\hline 900 to 949 & $-30 \%$ & 18.6 & 16.1 & 31 \\
\hline 950 to 1000 & $-30 \%$ & 18.6 & 15.3 & 29 \\
\hline
\end{tabular}

\section{FUZZY CONTROLLER DESIGN}

In order to design a Fuzzy Inference System (FIS) to control the level of cane fibers in Donnelly chute, we must describe the operation of system linguistically. A text block of FIS is shown in Fig.6. Four components of a fuzzy controller are fuzzifier, rule base, inference engine and defuzzifier [13] [14] [15].

It has been calculated that the flow rate is $26.6 \mathrm{Kg} / \mathrm{cm}$ which will remain constant whereas the feed rate will be varied depending on the height of cane in chute and amount of cane available in rake carrier. The rate at which cane is dumped in chute is known as feed rate and the rate at which cane is crushed by the rolls of mill is called flow rate.

When the cane level in chute is at $0 \mathrm{~cm}, 30 \mathrm{~cm}$ or $60 \mathrm{~cm}$ then the feed rate of cane is increased by $30 \%, 20 \%$ or $10 \%$ of flow rate. If the cane level in chute is at $90 \mathrm{~cm}$ then the feed rate of cane should be same as flow rate of cane i.e. $26.6 \mathrm{Kg} . / \mathrm{sec}$. If the cane level in chute is at $120 \mathrm{~cm}, 150 \mathrm{~cm}$ or $180 \mathrm{~cm}$ then the feed rate is decreased by $10 \%, 20 \%$ or $30 \%$ of flow rate. The control algorithm to design a fuzzy controller is shown in Table 5.
Two input parameters selected for the fuzzy controller are 'HEIGHT' and 'WEIGHT'.

Input parameter 'HEIGHT' measures the level of cane fiber in Donnelly Chute in centimeters and input parameter 'WEIGHT' measures the weight of cane in cane carrier in Kilograms. The output parameter selected for this design is 'SPEED' which is the speed of the carrier motor in rpm.

The universe of discourse of input parameter 'HEIGHT' is in the range 0 to $180 \mathrm{~cm}$ and its graphical representation is shown in Fig.7. The universe of discourse of the input parameter 'HEIGHT' is fuzzified into seven triangular linguistic variables as follows:

\author{
EL (Extreme Low): [0 30] \\ VL (Very Low): [0 30 60] \\ L (Low): [30 60 90] \\ JR (Just Right): [60 90 120] \\ H (High): [90 120 150] \\ VH (Very High): [120 150 180] \\ EH (Extreme High): [150 180]
}

The universe of discourse of input parameter 'WEIGHT' is in the range $500 \mathrm{Kg}$ to $1000 \mathrm{Kg}$ and its graphical representation is shown in Fig.8. The universe of discourse of the input parameter 'WEIGHT' is fuzzified into eleven triangular linguistic variables as follows:
SL (Super Low): [500 550]
UL (Ultra Low): [500 550 600]
EL (Extreme Low): [550 600 650]
VL (Very Low): [600 650 700]
L (Low): [650 700750$]$
JR (Just Right): [700 750 800]
H (High): [750 800 850]
VH (Very High): [800 850 900]
EH (Extreme High): [850 900 950]
UH (Ultra High): [900 950 1000]
SH (Super High): [950 1000]

The universe of discourse of output parameter 'SPEED' is in the range 28RPM to 106RPM and its graphical representation is shown in Fig.9. The universe of discourse of the output parameter 'SPEED' is fuzzified into seven triangular linguistic variables as follows:

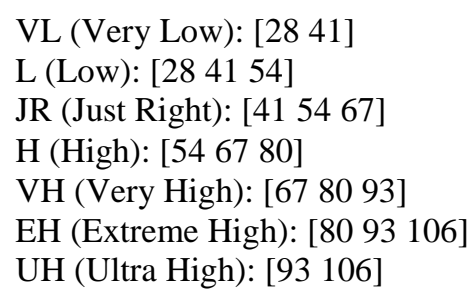

Each triangular membership function of input and output parameters has $50 \%$ overlaps with its neighbor membership function.

The surface viewer of FIS is shown in Fig.10. The fuzzy rules can be represented by a fuzzy associative memory (FAM) table as represented in Table 4 [15]. The fuzzy rules are developed for the fuzzy controller which 
produces appropriate speed indication to run the cane carrier motor depending upon the height of cane fiber in Donnelly chute and weight of cane in cane carrier. Since the input parameter 'HEIGHT' is fuzzified into seven linguistic variables and the input parameter 'WEIGHT' is fuzzified into eleven linguistic variables therefore there arises seventy seven rules.

The fuzzy design in this work incorporates Mamdani's implication method of inference, which is one of the most popular methods in fuzzy control applications [16] [17].
A simulation run was performed on the MATLAB platform for four different cases of varying cane load and varying cane level and result is shown in Table 7.

Example 1 - The rule viewer of the system which is obtained after experiment is shown in Fig. 6 which shows the condition when cane height in chute is $60 \mathrm{~cm}$ and cane weight in rake carrier is $550 \mathrm{Kg}$. Under these conditions fuzzy controller will run the rake carrier motor at $80 \mathrm{rpm}$ (Fig. 11) and rake carrier will run at $41.9 \mathrm{~cm} / \mathrm{s}$.

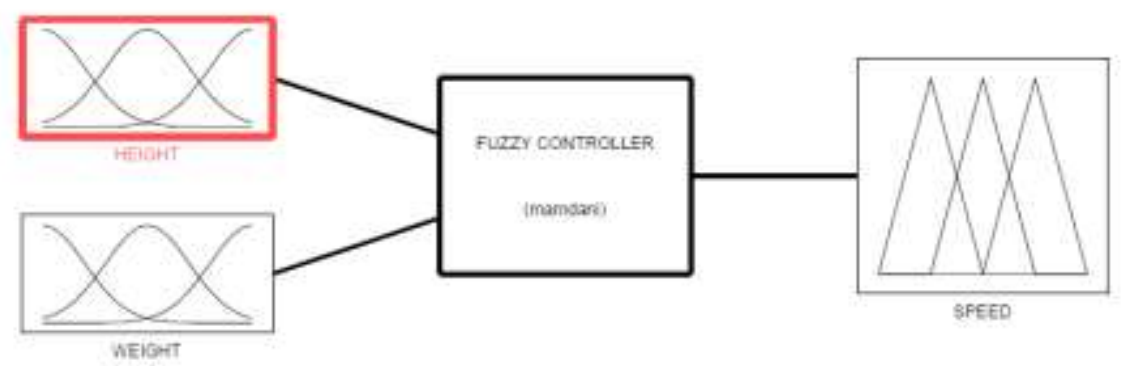

Fig. 6. Text Blocks Explaining the Objects of FIS

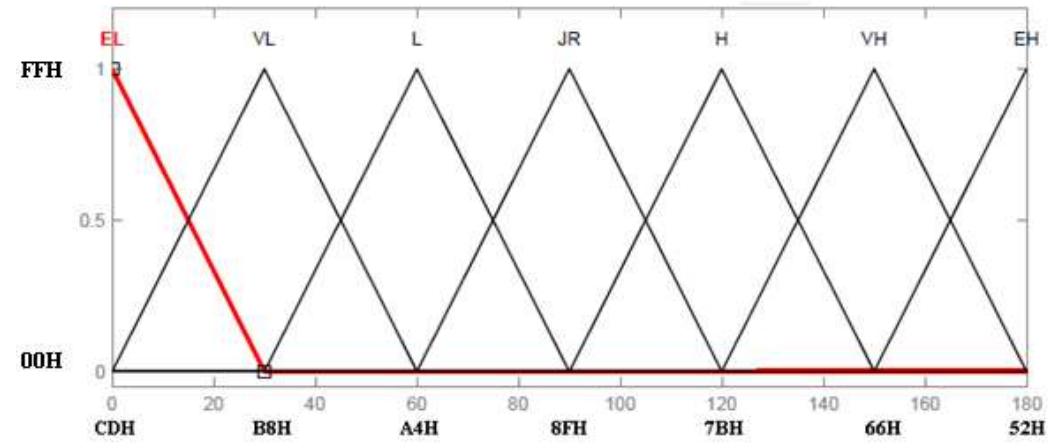

Fig. 7. Membership Function of 'HEIGHT'

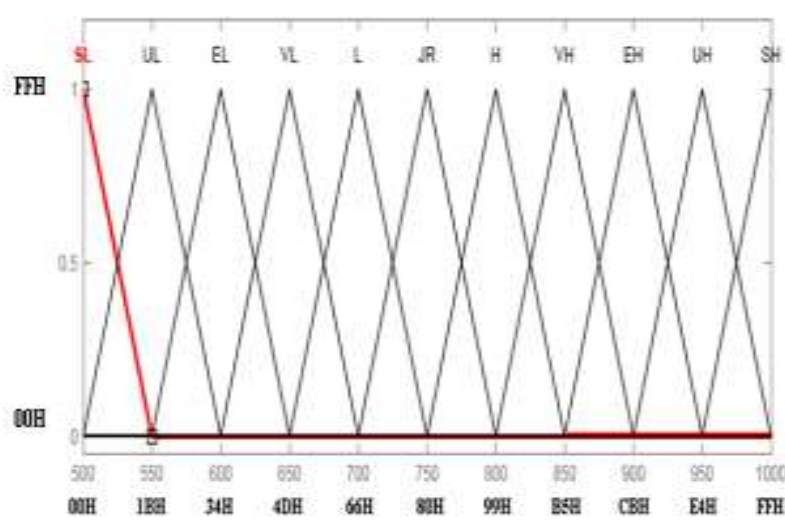

Fig. 8. Membership Function of 'WEIGHT'

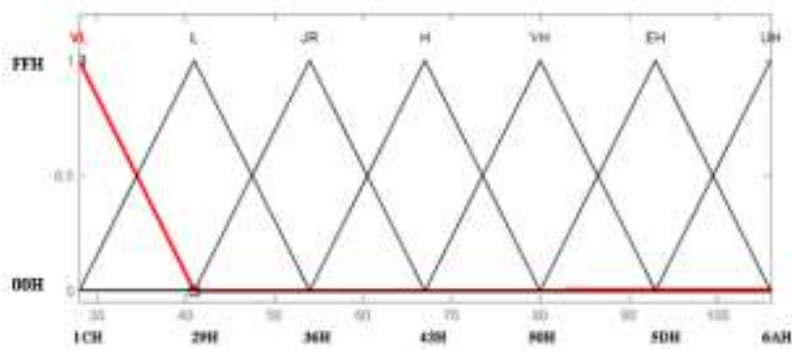

Fig. 9. Membership Function of 'SPEED'

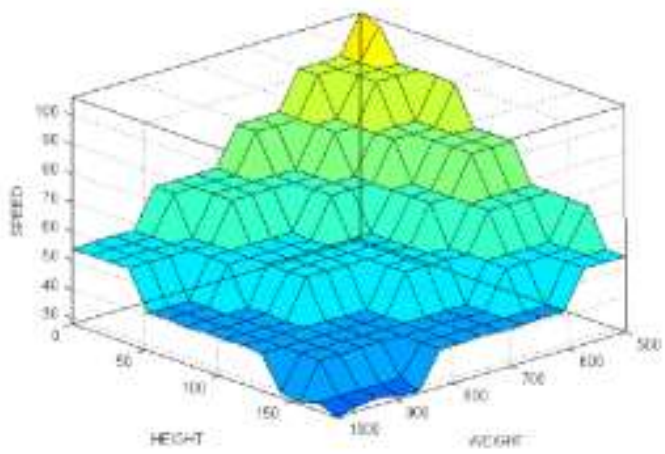

Fig. 10. Surface Viewer of FIS

Table 4. Fuzzy Rule Matrix

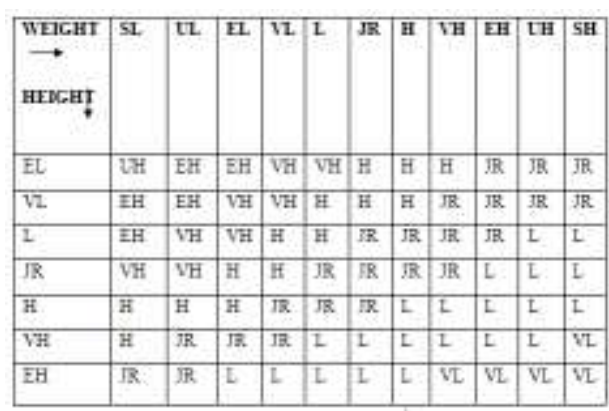


Design Algorithm and Performance Analysis of

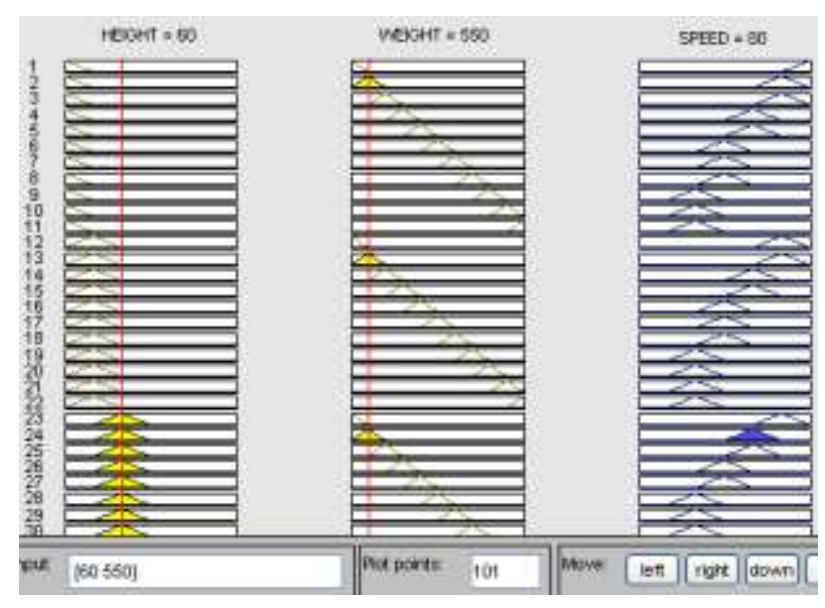

Fig. 11 . Height $=60 \mathrm{~cm}$, Weight $=550 \mathrm{Kg}$ and $\mathrm{RPM}=80 \mathrm{RPM}$

Table 5. Fuzzy Controller Design Algorithm

\begin{tabular}{|c|c|c|c|c|}
\hline $\begin{array}{c}\text { Cane } \\
\text { weight } \\
\text { ( Kg) }\end{array}$ & $\begin{array}{c}\text { Variation } \\
\text { of Feed } \\
\text { Rate Flow } \\
\text { Rate }(\%)\end{array}$ & $\begin{array}{c}\text { Feed } \\
\text { rate } \\
(\mathrm{Kg} / \mathbf{s})\end{array}$ & $\begin{array}{c}\text { Carrier } \\
\text { Speed } \\
(\mathrm{cm} / \mathrm{s})\end{array}$ & $\begin{array}{l}\text { Motor } \\
\text { Speed } \\
\text { (rpm) }\end{array}$ \\
\hline \multicolumn{5}{|c|}{ Cane Level in Chute $=0 \mathrm{~cm}(\mathrm{EL})$} \\
\hline $500(\mathrm{SL})$ & $+30 \%$ & 34.6 & 55.4 & 105.8 \\
\hline 550 (UL) & $+30 \%$ & 34.6 & 50.3 & 96.1 \\
\hline 600 (EL) & $+30 \%$ & 34.6 & 46.1 & 88.1 \\
\hline $650(\mathrm{VL})$ & $+30 \%$ & 34.6 & 42.6 & 81.4 \\
\hline $700(\mathrm{~L})$ & $+30 \%$ & 34.6 & 39.5 & 75.4 \\
\hline $750(\mathrm{JR})$ & $+30 \%$ & 34.6 & 36.9 & 70.5 \\
\hline $800(\mathrm{H})$ & $+30 \%$ & 34.6 & 34.6 & 66.1 \\
\hline $850(\mathrm{VH})$ & $+30 \%$ & 34.6 & 32.5 & 62.1 \\
\hline $900(\mathrm{EH})$ & $+30 \%$ & 34.6 & 30.8 & 58.8 \\
\hline $950(\mathrm{UH})$ & $+30 \%$ & 34.6 & 29.1 & 55.6 \\
\hline $1000(\mathrm{SH})$ & $+30 \%$ & 34.6 & 27.7 & 52.9 \\
\hline \multicolumn{5}{|c|}{ Cane Level in Chute $=30 \mathrm{~cm}(\mathrm{VL})$} \\
\hline $500(\mathrm{SL})$ & $+20 \%$ & 31.9 & 51 & 97.4 \\
\hline 550 (UL) & $+20 \%$ & 31.9 & 46.4 & 88.6 \\
\hline 600 (EL) & $+20 \%$ & 31.9 & 42.5 & 81.2 \\
\hline $650(\mathrm{VL})$ & $+20 \%$ & 31.9 & 39.2 & 74.9 \\
\hline $700(\mathrm{~L})$ & $+20 \%$ & 31.9 & 36.5 & 69.7 \\
\hline $750(\mathrm{JR})$ & $+20 \%$ & 31.9 & 34 & 64.9 \\
\hline $800(\mathrm{H})$ & $+20 \%$ & 31.9 & 31.9 & 60.9 \\
\hline $850(\mathrm{VH})$ & $+20 \%$ & 31.9 & 30 & 57.3 \\
\hline $900(\mathrm{EH})$ & $+20 \%$ & 31.9 & 28.4 & 54.2 \\
\hline $950(\mathrm{UH})$ & $+20 \%$ & 31.9 & 26.9 & 51.4 \\
\hline $1000(\mathrm{SH})$ & $+20 \%$ & 31.9 & 25.5 & 48.7 \\
\hline \multicolumn{5}{|c|}{ Cane Level in Chute $=60 \mathrm{~cm}(\mathrm{~L})$} \\
\hline $500(\mathrm{SL})$ & $+10 \%$ & 29.3 & 46.9 & 89.6 \\
\hline 550 (UL) & $+10 \%$ & 29.3 & 42.6 & 81.4 \\
\hline $600(\mathrm{EL})$ & $+10 \%$ & 29.3 & 39.1 & 74.7 \\
\hline $650(\mathrm{VL})$ & $+10 \%$ & 29.3 & 36 & 68.8 \\
\hline $700(\mathrm{~L})$ & $+10 \%$ & 29.3 & 33.5 & 64 \\
\hline $750(\mathrm{JR})$ & $+10 \%$ & 29.3 & 31.2 & 59.6 \\
\hline $800(\mathrm{H})$ & $+10 \%$ & 29.3 & 29.3 & 56 \\
\hline $850(\mathrm{VH})$ & $+10 \%$ & 29.3 & 27.6 & 52.7 \\
\hline 900 (EH) & $+10 \%$ & 29.3 & 26 & 49.7 \\
\hline $950(\mathrm{UH})$ & $+10 \%$ & 29.3 & 24.7 & 47.2 \\
\hline
\end{tabular}




\section{RESULT AND DISCUSSION}

(A) Case 1 of conventional controller - At 0s cane Level is $10 \mathrm{~cm}$ and cane weight on rake carrier is $600 \mathrm{Kg}$ then the motor speed will be $85 \mathrm{rpm}$ and the rake carrier speed will be $44.5 \mathrm{~cm} / \mathrm{s}$. The carrier has $0.75 \mathrm{Kg} / \mathrm{cm}$ cane on carrier therefore the feed rate will be $33.4 \mathrm{Kg} / \mathrm{s}$. Since the flow rate is constant at $26.6 \mathrm{Kg} / \mathrm{s}$ therefore $6.8 \mathrm{Kg}$ cane is in excess in chute in every second. Re-sampling is done after every $10 \mathrm{sec}$. Therefore after $10 \mathrm{~s}$ there is $68 \mathrm{Kg}$ cane is in excess in chute. In the chute $2.8 \mathrm{Kg}$ cane is occupied in $1 \mathrm{~cm}$ height of chute therefore $68 \mathrm{Kg}$ cane in chute will cover $24.3 \mathrm{~cm}$ of chute in height. Since the cane level was at $10 \mathrm{~cm}$ at $0 \mathrm{~s}$ therefore after $10 \mathrm{sec}$ the cane level in chute will be $34.3 \mathrm{~cm}$.

At $10 \mathrm{~s}$ cane level is $34.3 \mathrm{~cm}$ and cane weight on rake carrier remains same $600 \mathrm{Kg}$ then the motor speed, rake carrier speed and feed rate will be $78 \mathrm{rpm}, 40.8 \mathrm{~cm} / \mathrm{s}$ and $30.6 \mathrm{Kg} / \mathrm{s}$ respectively. Since the flow rate is constant at $26.6 \mathrm{Kg} / \mathrm{s}$ therefore after $20 \mathrm{sec}$ there is $40 \mathrm{Kg}$ excess cane in chute which covers $14.3 \mathrm{~cm}$ height of chute. Since the cane level was at $34.3 \mathrm{~cm}$ at $10 \mathrm{sec}$ therefore after $20 \mathrm{~s}$ the cane level in chute will be $48.6 \mathrm{~cm}$.

At 20 s cane level is $48.6 \mathrm{~cm}$ and cane weight on rake carrier remains same $600 \mathrm{Kg}$ then the motor speed and the rake carrier speed will remain same as $78 \mathrm{rpm}$ and $40.8 \mathrm{~cm} / \mathrm{s}$ respectively. Since there is no change in rake carrier speed and cane weight on carrier therefore the feed rate will also remains same i.e. $30.6 \mathrm{Kg} / \mathrm{s}$. Since the flow rate remains constant at $26.6 \mathrm{Kg} / \mathrm{s}$ therefore after $30 \mathrm{sec}$ there is $40 \mathrm{Kg}$ excess cane in chute which covers $14.3 \mathrm{~cm}$ height of chute. Since the cane level was at $48.6 \mathrm{~cm}$ at 20 s therefore after 30 s the cane level in chute will be $62.9 \mathrm{~cm}$.

At $30 \mathrm{~s}$ cane level is $62.9 \mathrm{~cm}$ and cane weight on rake carrier remains same $600 \mathrm{Kg}$ then the motor speed will be $72 \mathrm{rpm}$ and the rake carrier speed will be $37.7 \mathrm{~cm} / \mathrm{s}$. Since there is no change in cane weight on carrier therefore the feed rate will be $28.3 \mathrm{Kg} / \mathrm{s}$. Since the flow rate remains constant at $26.6 \mathrm{Kg} / \mathrm{s}$ therefore after $40 \mathrm{sec}$ there is $17 \mathrm{Kg}$ excess cane in chute which covers $6.1 \mathrm{~cm}$ height of chute. Since the cane level was at $62.9 \mathrm{~cm}$ at $30 \mathrm{~s}$ therefore after $40 \mathrm{~s}$ the cane level in chute will be $69.0 \mathrm{~cm}$.

At $40 \mathrm{~s}$ cane level is $69.0 \mathrm{~cm}$ and cane weight on rake carrier remains same $600 \mathrm{Kg}$ then the motor speed, the rake carrier speed and feed rate will remain same as $72 \mathrm{rpm}, 37.7 \mathrm{~cm} / \mathrm{s}$ and $28.3 \mathrm{Kg} / \mathrm{cm}$ respectively. After $50 \mathrm{sec}$ there is $17 \mathrm{Kg}$ excess cane in chute which covers $6.1 \mathrm{~cm}$ height of chute. Since the cane level was at $69.0 \mathrm{~cm}$ at $40 \mathrm{~s}$ therefore after $50 \mathrm{~s}$ the cane level in chute will be $75.1 \mathrm{~cm}$.

At $50 \mathrm{~s}$ cane level is $75.1 \mathrm{~cm}$ and cane weight on rake carrier remains same $600 \mathrm{Kg}$ then the motor speed, the rake carrier speed and feed rate will remain same as $72 \mathrm{rpm}, 37.7 \mathrm{~cm} / \mathrm{s}$ and $28.3 \mathrm{Kg} / \mathrm{cm}$ respectively. After $60 \mathrm{~s}$ there is $17 \mathrm{Kg}$ excess cane in chute which covers $6.1 \mathrm{~cm}$ height of chute. Since the cane level was at $75.1 \mathrm{~cm}$ at $50 \mathrm{~s}$ therefore after $60 \mathrm{~s}$ the cane level in chute will be $81.2 \mathrm{~cm}$.

At $60 \mathrm{~s}$ cane level is $81.2 \mathrm{~cm}$ and cane weight on rake carrier remains same $600 \mathrm{Kg}$ then the motor speed will be
$65 \mathrm{rpm}$ and the rake carrier speed will be $34.0 \mathrm{~cm} / \mathrm{s}$. Since there is no change in cane weight on carrier therefore the feed rate will be $25.5 \mathrm{Kg} / \mathrm{s}$. Since the flow rate remains constant at $26.6 \mathrm{Kg} / \mathrm{s}$ therefore after $70 \mathrm{sec}$ there is $11 \mathrm{Kg}$ less cane in chute which covers $3.9 \mathrm{~cm}$ height of chute. Since the cane level was at $81.2 \mathrm{~cm}$ at $60 \mathrm{~s}$ therefore after 70 s the cane level in chute will be $77.3 \mathrm{~cm}$. Result of all the four cases of conventional controller is shown in Table 6.

(B) Case 1 of fuzzy controller - At 0s cane Level is $10 \mathrm{~cm}$ and cane weight on rake carrier is $600 \mathrm{Kg}$ then the motor speed will be $88.3 \mathrm{rpm}$ [Fig. 12] and the rake carrier speed will be $46.2 \mathrm{~cm} / \mathrm{s}$. The carrier has $0.75 \mathrm{Kg} / \mathrm{cm}$ cane on carrier therefore the feed rate will be $34.7 \mathrm{Kg} / \mathrm{s}$. Since the flow rate is constant at $26.6 \mathrm{Kg} / \mathrm{s}$ therefore $8.1 \mathrm{Kg}$ cane is in excess in chute in every second. Resampling is done after every 10s. Therefore after 10 seconds there is $81 \mathrm{Kg}$ cane is in excess in chute. In the chute $2.8 \mathrm{Kg}$ cane is occupied in $1 \mathrm{~cm}$ height of chute therefore $81 \mathrm{Kg}$ cane in chute will cover $29.0 \mathrm{~cm}$ of chute in height. Since the cane level was at $10 \mathrm{~cm}$ at $0 \mathrm{~s}$ therefore after $10 \mathrm{~s}$ the cane level in chute will be $39.0 \mathrm{~cm}$.

At $10 \mathrm{~s}$ cane level is $39.0 \mathrm{~cm}$ and cane weight on rake carrier remains same $600 \mathrm{Kg}$ then the motor speed, rake carrier speed and feed rate will be 80rpm [Fig. 13], $42.0 \mathrm{~cm} / \mathrm{s}$ and $31.5 \mathrm{Kg} / \mathrm{s}$ respectively. Since the flow rate is constant at $26.6 \mathrm{Kg} / \mathrm{s}$ therefore after $20 \mathrm{sec}$ there is $49 \mathrm{Kg}$ excess cane in chute which covers $17.5 \mathrm{~cm}$ height of chute. Since the cane level was at $39.0 \mathrm{~cm}$ at $10 \mathrm{~s}$ therefore after $20 \mathrm{~s}$ the cane level in chute will be $56.5 \mathrm{~cm}$.

At $20 \mathrm{~s}$ cane level is $56.5 \mathrm{~cm}$ and cane weight on rake carrier remains same $600 \mathrm{Kg}$ then the motor speed [Fig. 14], rake carrier speed and feed rate will remain same as of earlier condition. Since the flow rate is constant therefore after $30 \mathrm{sec}$ there is $49 \mathrm{Kg}$ excess cane in chute which covers $17.5 \mathrm{~cm}$ height of chute. Since the cane level was at $56.5 \mathrm{~cm}$ at $20 \mathrm{~s}$ therefore after $30 \mathrm{~s}$ the cane level in chute will be $74.0 \mathrm{~cm}$.

At $30 \mathrm{~s}$ cane level is $74.0 \mathrm{~cm}$ and cane weight on rake carrier remains same $600 \mathrm{Kg}$ then the motor speed, rake carrier speed and feed rate will be 73.8rpm [Fig.15], $38.6 \mathrm{~cm} / \mathrm{s}$ and $29.0 \mathrm{Kg} / \mathrm{s}$ respectively. Since the flow rate is constant at $26.6 \mathrm{Kg} / \mathrm{s}$ therefore after $40 \mathrm{sec}$ there is $24 \mathrm{Kg}$ excess cane in chute which covers $8.6 \mathrm{~cm}$ height of chute. Since the cane level was at $74.0 \mathrm{~cm}$ at $30 \mathrm{~s}$ therefore after $40 \mathrm{~s}$ the cane level in chute will be $82.6 \mathrm{~cm}$.

At 40 s cane level is $82.6 \mathrm{~cm}$ and cane weight on rake carrier remains same $600 \mathrm{Kg}$ then the motor speed, rake carrier speed and feed rate will be 70.7rpm [Fig. 16], $37.0 \mathrm{~cm} / \mathrm{s}$ and $27.8 \mathrm{Kg} / \mathrm{s}$ respectively. Since the flow rate is constant at $26.6 \mathrm{Kg} / \mathrm{s}$ therefore after $50 \mathrm{sec}$ there is $12 \mathrm{Kg}$ excess cane in chute which covers $4.3 \mathrm{~cm}$ height of chute. Since the cane level was at $82.6 \mathrm{~cm}$ at 40 s therefore after $50 \mathrm{~s}$ the cane level in chute will be $86.9 \mathrm{~cm}$.

At $50 \mathrm{~s}$ cane level is $86.9 \mathrm{~cm}$ and cane weight on rake carrier remains same $600 \mathrm{Kg}$ then the motor speed, rake carrier speed and feed rate will be 68.8rpm [Fig. 17], $36.0 \mathrm{~cm} / \mathrm{s}$ and $27.0 \mathrm{Kg} / \mathrm{s}$ respectively. Since the flow rate is constant at $26.6 \mathrm{Kg} / \mathrm{s}$ therefore after $60 \mathrm{~s}$ there is $4 \mathrm{Kg}$ excess cane in chute which covers $1.4 \mathrm{~cm}$ height of chute. 
Since the cane level was at $86.9 \mathrm{~cm}$ at $50 \mathrm{~s}$ therefore after 60 s the cane level in chute will be $88.3 \mathrm{~cm}$.

At $60 \mathrm{~s}$ cane level is $88.3 \mathrm{~cm}$ and cane weight on rake carrier remains same $600 \mathrm{Kg}$ then the motor speed, rake carrier speed and feed rate will be $68.0 \mathrm{rpm}, 35.6 \mathrm{~cm} / \mathrm{s}$ and $26.7 \mathrm{Kg} / \mathrm{s}$ respectively. Since the flow rate is constant at $26.6 \mathrm{Kg} / \mathrm{s}$ therefore after $70 \mathrm{sec}$ there is $1 \mathrm{Kg}$ excess cane in chute which covers $0.4 \mathrm{~cm}$ height of chute. Since the cane level was at $88.3 \mathrm{~cm}$ at $60 \mathrm{~s}$ therefore after $70 \mathrm{~s}$ the cane level in chute will be $88.7 \mathrm{~cm}$.

The comparison of performance of conventional and fuzzy controllers is shown in Fig. 18 to Fig. 21.

\section{CONCLUSION}

A fuzzy controller shows better result as compare to conventional controller in maintaining the cane level at $90 \mathrm{~cm}$ in chute. If the cane level is maintained at $90 \mathrm{~cm}$ for specified mill parameters then pressure due to cane column in chute will be maintained at $2 \mathrm{kPa}$ which reduce the bagasse failure rate at 0.04 and finally cane juice extraction from the mill will enhanced.

The fuzzy control algorithm is based on the operator's experience and field tests. The essence of fuzzy control algorithms is a conditional statement between a fuzzy input variable and a fuzzy output variable. The benefits of fuzzy controllers could be summarized as follows:

(i) Fuzzy controllers are more robust than conventional controller because they can operate with noise and disturbances of different nature.

(ii) Developing a fuzzy controller is cheaper than developing a model-based controller.

(iii) Fuzzy controllers are customizable, since it is easier to understand and modify their rule, which not only use a human operator's strategy, but also are expressed in natural linguistic terms.

(iv) It is easy to learn how fuzzy controllers operate and how to design and apply them to a concrete application

Table 6. Various Cases of Conventional Controller

\begin{tabular}{|c|c|c|c|c|c|c|c|}
\hline \multicolumn{8}{|c|}{ CASE I - Cane at $10 \mathrm{~cm}$ in Chute and Cane in Rake Carrier is Constant at $600 \mathrm{Kg}$} \\
\hline Parameters & At $0 \mathrm{~s}$ & At $10 \mathrm{~s}$ & At $20 \mathrm{~s}$ & At $30 \mathrm{~s}$ & At $40 \mathrm{~s}$ & At $50 \mathrm{~s}$ & At $60 \mathrm{~s}$ \\
\hline Cane Level (cm) & 10 & 34.3 & 48.6 & 62.9 & 69.0 & 75.1 & 81.2 \\
\hline Cane Weight $(\mathrm{Kg})$ & 600 & 600 & 600 & 600 & 600 & 600 & 600 \\
\hline Motor Speed (rpm) & 85 & 78 & 78 & 72 & 72 & 72 & 65 \\
\hline Carrier Speed $(\mathrm{cm} / \mathrm{s})$ & 44.5 & 40.8 & 40.8 & 37.7 & 37.7 & 37.7 & 34.0 \\
\hline Cane In Carrier $(\mathrm{Kg} / \mathrm{cm})$ & 0.75 & 0.75 & 0.75 & 0.75 & 0.75 & 0.75 & 0.75 \\
\hline Feed Rate $(\mathrm{Kg} / \mathrm{s})$ & 33.4 & 30.6 & 30.6 & 28.3 & 28.3 & 28.3 & 25.5 \\
\hline Data for next sampling & $\begin{array}{l}+68 \mathrm{Kg} \\
+24.3 \mathrm{~cm}\end{array}$ & $\begin{array}{l}+40 \mathrm{Kg} \\
+14.3 \mathrm{~cm}\end{array}$ & $\begin{array}{l}+40 \mathrm{Kg} \\
+14.3 \mathrm{~cm}\end{array}$ & $\begin{array}{l}+17 \mathrm{Kg}, \\
+6.1 \mathrm{~cm}\end{array}$ & $\begin{array}{l}+17 \mathrm{Kg}, \\
+6.1 \mathrm{~cm}\end{array}$ & $\begin{array}{l}+17 \mathrm{Kg}, \\
+6.1 \mathrm{~cm}\end{array}$ & $\begin{array}{l}-11 \mathrm{Kg} \\
-3.9 \mathrm{~cm} \\
\end{array}$ \\
\hline $\begin{array}{l}\text { Cane Level for next } \\
\text { Sample }(\mathrm{cm})\end{array}$ & 34.3 & 48.6 & 62.9 & 69.0 & 75.1 & 81.2 & 77.3 \\
\hline \multicolumn{8}{|c|}{ CASE II - Cane at $10 \mathrm{~cm}$ and Cane is Varying in Rake Carrier } \\
\hline Parameters & At $0 \mathrm{~s}$ & At $10 \mathrm{~s}$ & At $20 \mathrm{~s}$ & At $30 \mathrm{~s}$ & At $40 \mathrm{~s}$ & At $50 \mathrm{~s}$ & At $60 \mathrm{~s}$ \\
\hline Cane Level $(\mathrm{cm})$ & 10 & 34.3 & 51.1 & 67.9 & 73.6 & 79.3 & 85 \\
\hline Cane Weight $(\mathrm{Kg})$ & 600 & 900 & 900 & 900 & 900 & 900 & 900 \\
\hline Motor Speed (rpm) & 85 & 53 & 53 & 48 & 48 & 48 & 44 \\
\hline Carrier Speed $(\mathrm{cm} / \mathrm{s})$ & 44.5 & 27.8 & 27.8 & 25.1 & 25.1 & 25.1 & 20.0 \\
\hline Cane In Carrier $(\mathrm{Kg} / \mathrm{cm})$ & 0.75 & 1.125 & 1.125 & 1.125 & 1.125 & 1.125 & 1.125 \\
\hline Feed Rate $(\mathrm{Kg} / \mathrm{s})$ & 33.4 & 31.3 & 31.3 & 28.2 & 28.2 & 28.2 & 22.5 \\
\hline Data for next sampling & $\begin{array}{l}+68 \mathrm{Kg}, \\
+24.3 \mathrm{~cm} \\
\end{array}$ & $\begin{array}{l}+47 \mathrm{Kg}, \\
+16.8 \mathrm{~cm} \\
\end{array}$ & $\begin{array}{l}+47 \mathrm{Kg}, \\
+16.8 \mathrm{~cm} \\
\end{array}$ & $\begin{array}{l}+16 \mathrm{Kg}, \\
+5.7 \mathrm{~cm} \\
\end{array}$ & $\begin{array}{l}+16 \mathrm{Kg}, \\
+5.7 \mathrm{~cm} \\
\end{array}$ & $\begin{array}{l}+16 \mathrm{Kg}, \\
+5.7 \mathrm{~cm} \\
\end{array}$ & $\begin{array}{l}-41 \mathrm{Kg}, \\
-14.6 \mathrm{~cm} \\
\end{array}$ \\
\hline $\begin{array}{l}\text { Cane Level for next } \\
\text { Sample }(\mathrm{cm})\end{array}$ & 34.3 & 51.1 & 67.9 & 73.6 & 79.3 & 85 & 70.4 \\
\hline \multicolumn{8}{|c|}{ CASE III Cane at 50cm and Cane is Varying in Rake Carrier } \\
\hline Parameters & At $0 \mathrm{~s}$ & At $10 \mathrm{~s}$ & At $20 \mathrm{~s}$ & At $30 \mathrm{~s}$ & At $40 \mathrm{~s}$ & At $50 \mathrm{~s}$ & At $60 \mathrm{~s}$ \\
\hline Cane Level $(\mathrm{cm})$ & 50 & 65.4 & 71.1 & 77.5 & 83.6 & 78.6 & 82.9 \\
\hline Cane Weight $(\mathrm{Kg})$ & 800 & 900 & 700 & 600 & 500 & 500 & 500 \\
\hline Motor Speed (rpm) & 59 & 48 & 62 & 72 & 77 & 85 & 72 \\
\hline Carrier Speed $(\mathrm{cm} / \mathrm{s})$ & 30.9 & 25.1 & 32.5 & 37.7 & 40.3 & 44.5 & 37.7 \\
\hline Cane In Carrier $(\mathrm{Kg} / \mathrm{cm})$ & 1.000 & 1.125 & 0.875 & 0.75 & 0.625 & 0.625 & 0.625 \\
\hline Feed Rate $(\mathrm{Kg} / \mathrm{s})$ & 30.9 & 28.2 & 28.4 & 28.3 & 25.2 & 27.8 & 23.6 \\
\hline Data for next sampling & $\begin{array}{l}+43 \mathrm{Kg} \\
+15.4 \mathrm{~cm}\end{array}$ & $\begin{array}{l}+16 \mathrm{Kg} \\
+5.7 \mathrm{~cm} \\
\end{array}$ & $\begin{array}{l}+18 \mathrm{Kg} \\
+6.4 \mathrm{~cm} \\
\end{array}$ & $\begin{array}{l}+17 \mathrm{Kg} \\
+6.1 \mathrm{~cm}\end{array}$ & $\begin{array}{l}-14 \mathrm{Kg} \\
-5 \mathrm{~cm}\end{array}$ & $\begin{array}{l}+12 \mathrm{Kg} \\
+4.3 \mathrm{~cm}\end{array}$ & $\begin{array}{l}-30 \mathrm{Kg}, \\
-10.7 \mathrm{~cm}\end{array}$ \\
\hline $\begin{array}{l}\text { Cane Level for next } \\
\text { Sample }(\mathrm{cm})\end{array}$ & 65.4 & 71.1 & 77.5 & 83.6 & 78.6 & 82.9 & 72.2 \\
\hline
\end{tabular}




\begin{tabular}{|c|c|c|c|c|c|c|c|}
\hline \multicolumn{7}{|c|}{ CASE IV Cane at 90cm and Cane is Varying in Rake Carrier } \\
\hline Parameters & At 0s & At 10s & At 20s & At 30s & At 40s & At 50s & At 60s \\
\hline Cane Level $(\mathrm{cm})$ & 90 & 88.2 & 85.7 & 81.8 & 76.8 & 82.2 & 78.3 \\
\hline Cane Weight $(\mathrm{Kg})$ & 750 & 900 & 600 & 500 & 650 & 650 & 700 \\
\hline Motor Speed $(\mathrm{rpm})$ & 53 & 44 & 65 & 77 & 66 & 60 & 62 \\
\hline Carrier Speed $(\mathrm{cm} / \mathrm{s})$ & 27.8 & 23.0 & 34.0 & 40.3 & 34.6 & 31.4 & 32.5 \\
\hline Cane In Carrier $(\mathrm{Kg} / \mathrm{cm})$ & 0.938 & 1.125 & 0.75 & 0.625 & 0.813 & 0.813 & 0.875 \\
\hline Feed Rate $(\mathrm{Kg} / \mathrm{s})$ & 26.1 & 25.9 & 25.5 & 25.2 & 28.1 & 25.5 & 28.4 \\
\hline Data for next sampling & $-5 \mathrm{Kg}$, & $-7 \mathrm{Kg}$, & $-11 \mathrm{Kg}$, & $-14 \mathrm{Kg}$, & $+15 \mathrm{Kg}$, & $-11 \mathrm{Kg}$, & $+18 \mathrm{Kg}$, \\
+ & $-1.8 \mathrm{~cm}$ & $-2.5 \mathrm{~cm}$ & $-3.9 \mathrm{~cm}$ & $-5.0 \mathrm{~cm}$ & $+5.4 \mathrm{~cm}$ & $-3.9 \mathrm{~cm}$ & $+6.4 \mathrm{~cm}$ \\
\hline $\begin{array}{c}\text { Cane Level for } \\
\text { next Sample }(\mathrm{cm})\end{array}$ & 88.2 & 85.7 & 81.8 & 76.8 & 82.2 & 78.3 & 84.7 \\
\hline
\end{tabular}

Table 7. Various Cases of Fuzzy Controller

\begin{tabular}{|c|c|c|c|c|c|c|c|}
\hline \multicolumn{8}{|c|}{ CASE I - Cane at $10 \mathrm{~cm}$ in Chute and Cane in Rake Carrier is Constant at $600 \mathrm{Kg}$} \\
\hline Parameters & At 0 s & At $10 \mathrm{~s}$ & At $20 \mathrm{~s}$ & At 30 s & At $40 \mathrm{~s}$ & At $50 \mathrm{~s}$ & At $60 \mathrm{~s}$ \\
\hline Cane Level $(\mathrm{cm})$ & 10 & 39 & 56.5 & 74.0 & 82.6 & 86.9 & 88.3 \\
\hline Cane Weight $(\mathrm{Kg})$ & 600 & 600 & 600 & 600 & 600 & 600 & 600 \\
\hline Motor Speed (rpm) & 88.3 & 80 & 80 & 73.8 & 70.7 & 68.8 & 68.0 \\
\hline Carrier Speed $(\mathrm{cm} / \mathrm{s})$ & 46.2 & 42.0 & 42.0 & 38.6 & 37.0 & 36.0 & 35.6 \\
\hline Cane In Carrier $(\mathrm{Kg} / \mathrm{cm})$ & 0.75 & 0.75 & 0.75 & 0.75 & 0.75 & 0.75 & 0.75 \\
\hline Feed Rate $(\mathrm{Kg} / \mathrm{s})$ & 34.7 & 31.5 & 31.5 & 29.0 & 27.8 & 27.0 & 26.7 \\
\hline Data for next sampling & $\begin{array}{l}+81 \mathrm{Kg} \\
+29 \mathrm{~cm} \\
\end{array}$ & $\begin{array}{c}+49 \\
+17.5 \mathrm{~cm} \\
\end{array}$ & $\begin{aligned} &+49 \\
&+ 17.5 \mathrm{~cm} \\
&\end{aligned}$ & $\begin{array}{l}+24 \mathrm{Kg}, \\
+8.6 \mathrm{~cm} \\
\end{array}$ & $\begin{array}{l}+12 \mathrm{Kg}, \\
+4.3 \mathrm{~cm}\end{array}$ & $\begin{array}{l}+4 \mathrm{Kg}, \\
+1.4 \mathrm{~cm} \\
\end{array}$ & $\begin{array}{r}+1 \mathrm{Kg}, \\
+0.4 \mathrm{~cm} \\
\end{array}$ \\
\hline $\begin{array}{l}\text { Cane Level for next } \\
\text { Sample }(\mathrm{cm})\end{array}$ & 39 & 56.5 & 74.0 & 82.6 & 86.9 & 88.3 & 88.7 \\
\hline \multicolumn{8}{|c|}{ CASE II - Cane at $10 \mathrm{~cm}$ and Cane is Varying in Rake Carrier } \\
\hline Parameters & At 0 s & At $10 \mathrm{~s}$ & At $20 \mathrm{~s}$ & At 30 s & At $40 \mathrm{~s}$ & At $50 \mathrm{~s}$ & At $60 \mathrm{~s}$ \\
\hline Cane Level $(\mathrm{cm})$ & 10 & 39 & 57.6 & 76.2 & 80.5 & 81.2 & 81.6 \\
\hline Cane Weight $(\mathrm{Kg})$ & 600 & 900 & 900 & 900 & 900 & 900 & 900 \\
\hline Motor Speed (rpm) & 88.3 & 54 & 54 & 47.1 & 45.5 & 45.3 & 45.1 \\
\hline Carrier Speed $(\mathrm{cm} / \mathrm{s})$ & 46.2 & 28.3 & 28.3 & 24.7 & 23.8 & 23.7 & 23.6 \\
\hline Cane In Carrier $(\mathrm{Kg} / \mathrm{cm})$ & 0.75 & 1.125 & 1.125 & 1.125 & 1.125 & 1.125 & 1.125 \\
\hline Feed Rate $(\mathrm{Kg} / \mathrm{s})$ & 34.7 & 31.8 & 31.8 & 27.8 & 26.8 & 26.7 & 26.6 \\
\hline Data for next sampling & $\begin{array}{l}+81 \mathrm{Kg} \\
+29 \mathrm{~cm}\end{array}$ & $\begin{array}{l}+52 \mathrm{Kg} \\
+18.6 \mathrm{~cm}\end{array}$ & $\begin{array}{l}+52 \mathrm{Kg} \\
+18.6 \mathrm{~cm}\end{array}$ & $\begin{array}{l}+12 \mathrm{Kg}, \\
+4.3 \mathrm{~cm}\end{array}$ & $\begin{array}{l}+2 \mathrm{Kg} \\
+0.7 \mathrm{~cm}\end{array}$ & $\begin{array}{l}+1 \mathrm{Kg} \\
+0.4 \mathrm{~cm}\end{array}$ & 0 \\
\hline $\begin{array}{l}\text { Cane Level for next } \\
\text { Sample }(\mathrm{cm}) \\
\end{array}$ & 39 & 57.6 & 76.2 & 80.5 & 81.2 & 81.6 & 81.6 \\
\hline \multicolumn{8}{|c|}{ CASE III Cane at $50 \mathrm{~cm}$ and Cane is Varying in Rake Carrier } \\
\hline Parameters & At $0 \mathrm{~s}$ & At $10 \mathrm{~s}$ & At $20 \mathrm{~s}$ & At $30 \mathrm{~s}$ & At $40 \mathrm{~s}$ & At $50 \mathrm{~s}$ & At $60 \mathrm{~s}$ \\
\hline Cane Level $(\mathrm{cm})$ & 50 & 64.6 & 78.2 & 80.3 & 85.8 & 86.9 & 87.6 \\
\hline Cane Weight $(\mathrm{Kg})$ & 800 & 900 & 700 & 600 & 500 & 500 & 500 \\
\hline Motor Speed (rpm) & 58.7 & 51.5 & 59.4 & 71.6 & 82.3 & 81.8 & 81.4 \\
\hline Carrier Speed $(\mathrm{cm} / \mathrm{s})$ & 30.7 & 27.0 & 31.1 & 37.5 & 43.1 & 42.8 & 42.6 \\
\hline Cane In Carrier $(\mathrm{Kg} / \mathrm{cm})$ & 1.000 & 1.125 & 0.875 & 0.75 & 0.625 & 0.625 & 0.625 \\
\hline Feed Rate $(\mathrm{Kg} / \mathrm{s})$ & 30.7 & 30.4 & 27.2 & 28.1 & 26.9 & 26.8 & 26.6 \\
\hline Data for next sampling & $\begin{array}{l}+41 \mathrm{Kg} \\
+14.6 \mathrm{~cm}\end{array}$ & $\begin{array}{l}+38 \mathrm{Kg} \\
+13.6 \mathrm{~cm}\end{array}$ & $\begin{array}{l}+6 \mathrm{Kg}, \\
+2.1 \mathrm{~cm} \\
\end{array}$ & $\begin{array}{l}+15 \mathrm{Kg}, \\
+5.5 \mathrm{~cm}\end{array}$ & $\begin{array}{l}+3 \mathrm{Kg} \\
+1.1 \mathrm{~cm} \\
\end{array}$ & $\begin{array}{l}+2 \mathrm{Kg} \\
+0.7 \mathrm{~cm}\end{array}$ & 0 \\
\hline $\begin{array}{l}\text { Cane Level for next } \\
\text { Sample }(\mathrm{cm})\end{array}$ & 64.6 & 78.2 & 80.3 & 85.8 & 86.9 & 87.6 & 87.6 \\
\hline \multicolumn{8}{|c|}{ CASE IV Cane at 90cm and Cane is Varying in Rake Carrier } \\
\hline Parameters & At $0 \mathrm{~s}$ & At $10 \mathrm{~s}$ & At $20 \mathrm{~s}$ & At $30 \mathrm{~s}$ & At $40 \mathrm{~s}$ & At $50 \mathrm{~s}$ & At $60 \mathrm{~s}$ \\
\hline Cane Level $(\mathrm{cm})$ & 90 & 89.6 & 81.4 & 86.4 & 87.1 & 93.9 & 97.5 \\
\hline
\end{tabular}


Design Algorithm and Performance Analysis of

Conventional and Fuzzy Controller for Maintaining the Cane Level during Sugar Making Process

\begin{tabular}{|c|c|c|c|c|c|c|c|}
\hline Cane Weight (Kg) & 750 & 900 & 600 & 500 & 650 & 650 & 700 \\
\hline Motor Speed (rpm) & 54 & 41.3 & 71.2 & 82 & 67 & 64.8 & 54 \\
\hline Carrier Speed (cm/s) & 28.3 & 21.6 & 37.3 & 42.9 & 35.1 & 33.9 & 28.3 \\
\hline Cane In Carrier (Kg/cm) & 0.938 & 1.125 & 0.75 & 0.625 & 0.813 & 0.813 & 0.875 \\
\hline Feed Rate $(\mathrm{Kg} / \mathrm{s})$ & 26.5 & 24.3 & 28.0 & 26.8 & 28.5 & 27.6 & 24.8 \\
\hline Data for next sampling & $\begin{array}{c}-1 \mathrm{Kg}, \\
-0.4 \mathrm{~cm}\end{array}$ & $\begin{array}{c}-23 \mathrm{Kg}, \\
-8.2 \mathrm{~cm}\end{array}$ & $\begin{array}{c}+14 \mathrm{Kg}, \\
+5 \mathrm{~cm}\end{array}$ & $\begin{array}{c}+2 \mathrm{Kg}, \\
+0.7 \mathrm{~cm}\end{array}$ & $\begin{array}{c}+19 \mathrm{Kg}, \\
+6.8 \mathrm{~cm}\end{array}$ & $\begin{array}{c}+10 \mathrm{Kg}, \\
+3.6 \mathrm{~cm}\end{array}$ & $\begin{array}{c}-18 \mathrm{Kg}, \\
-6.4 \mathrm{~cm}\end{array}$ \\
\hline $\begin{array}{c}\text { Cane Level for next } \\
\text { Sample (cm) }\end{array}$ & 89.6 & 81.4 & 86.4 & $87.1 \mathrm{~cm}$ & 93.9 & 97.5 & 91.1 \\
\hline
\end{tabular}

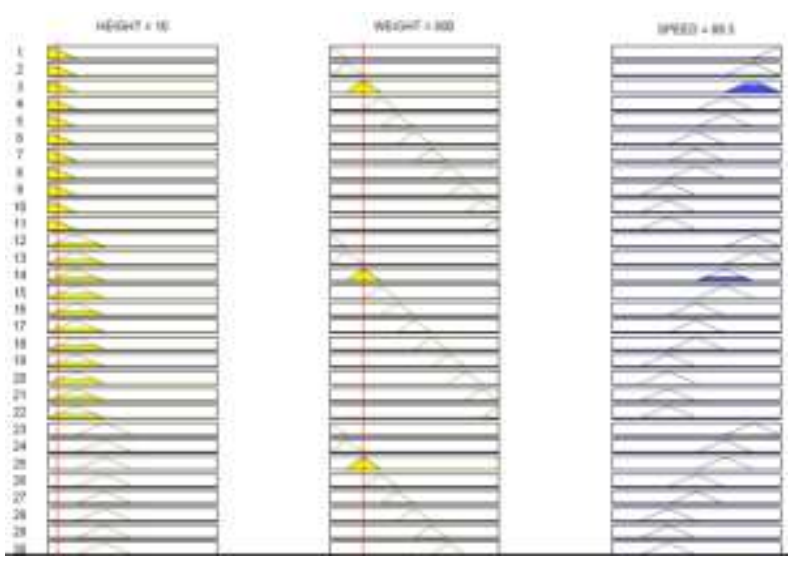

Fig. 12.

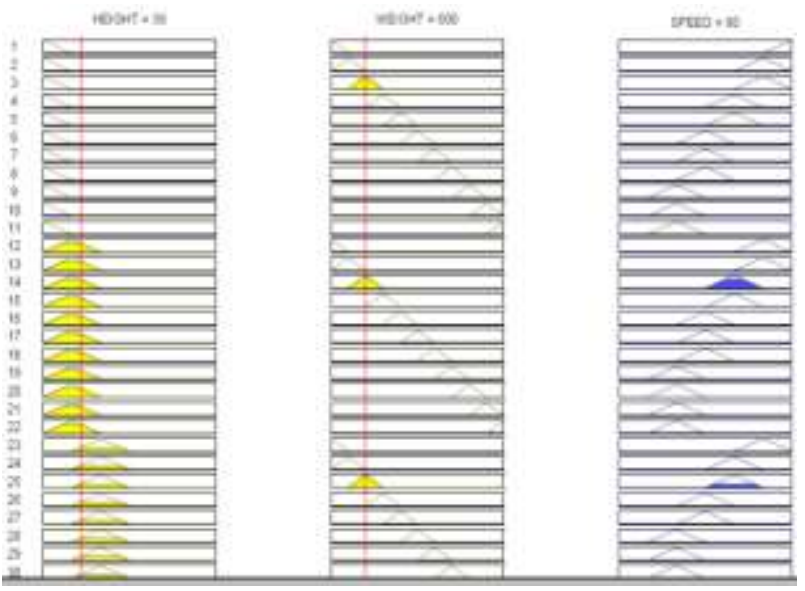

Fig. 13.

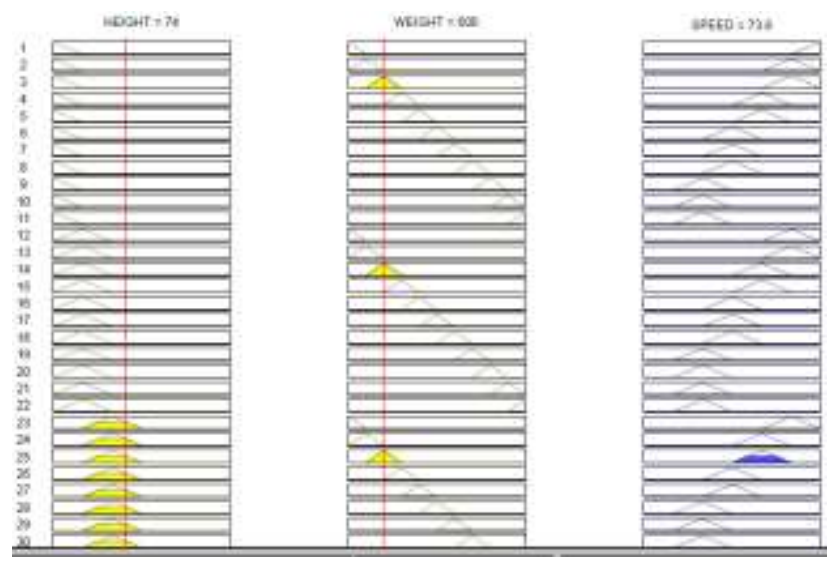

Fig. 14.

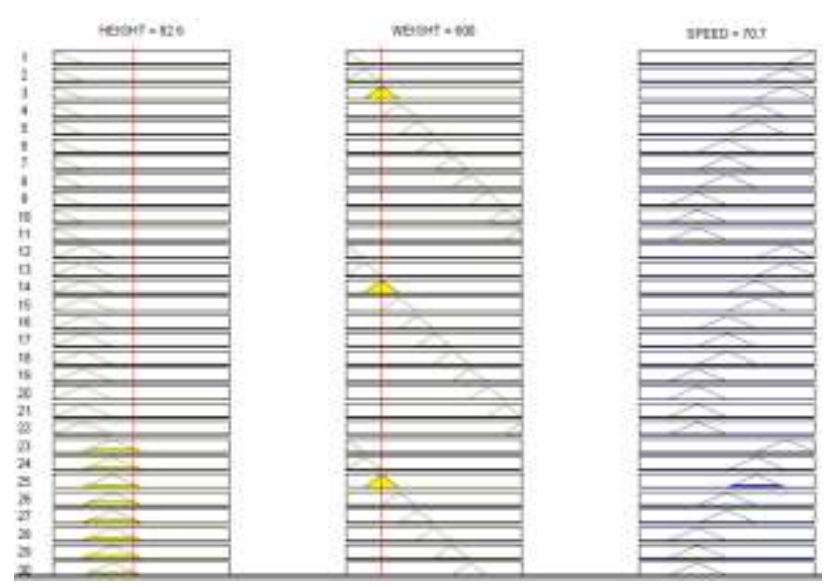

Fig. 15 .

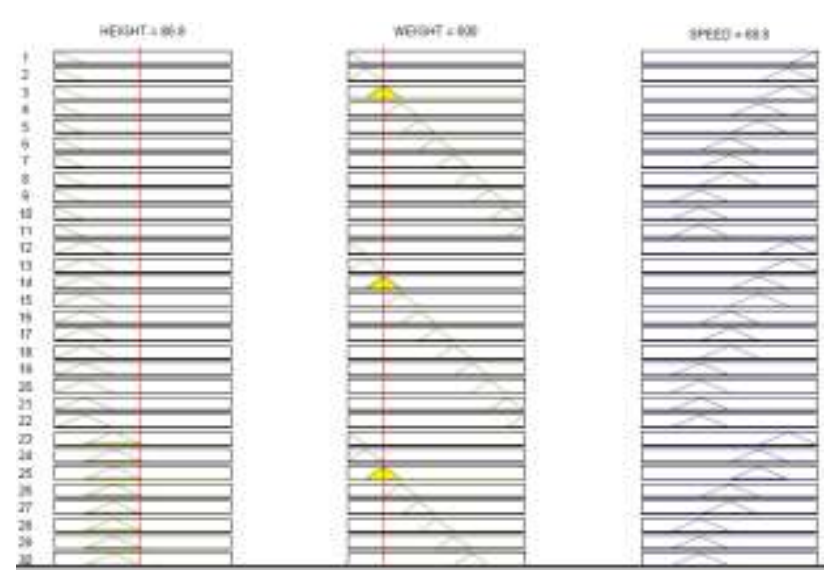

Fig. 16.

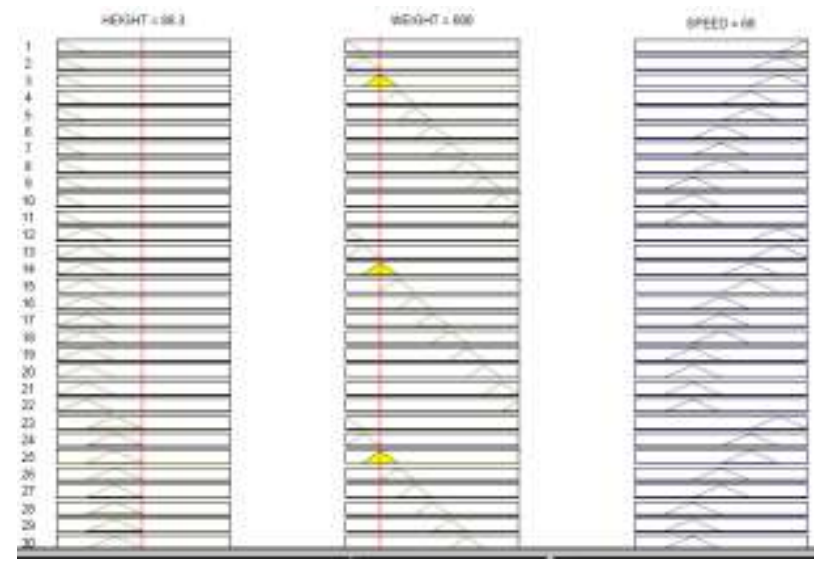

Fig. 17. 


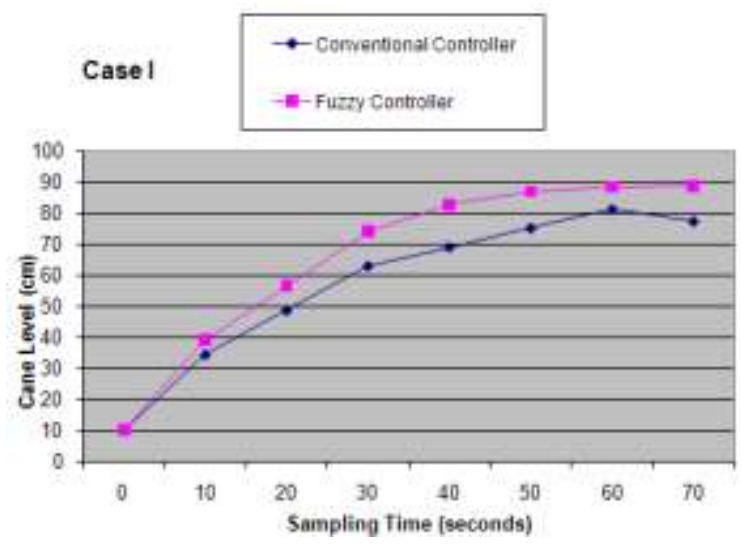

Fig.18. Case - I

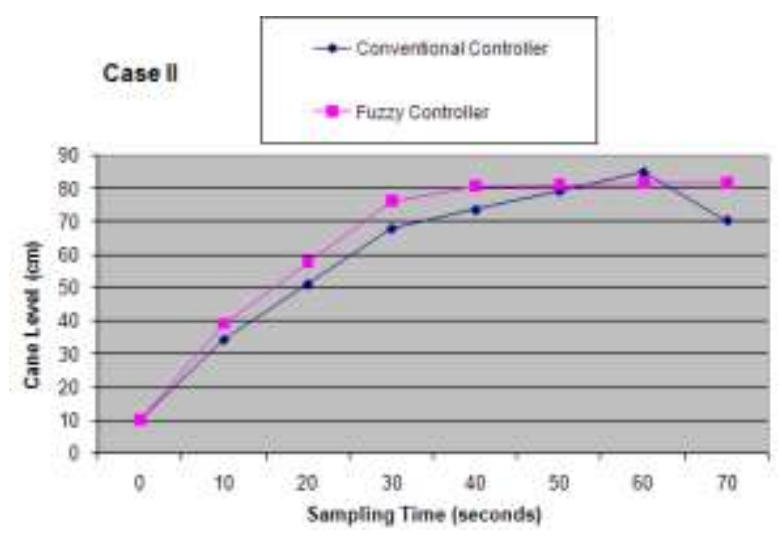

Fig. 19. Case - II

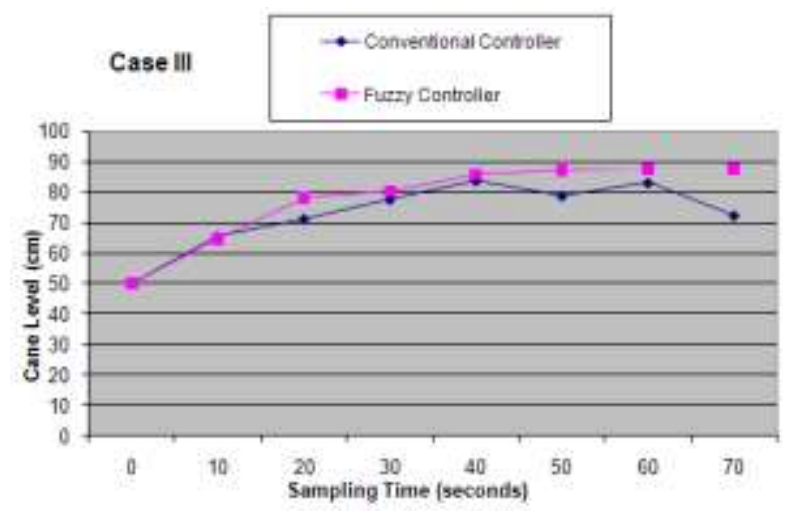

Fig.20. Case - III

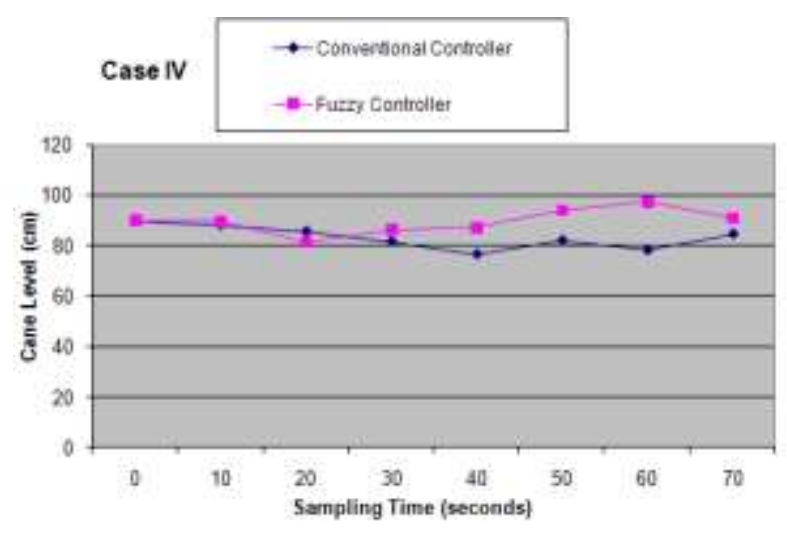

Fig. 21. Case - IV

\section{REFERENCES}

[1] D.P Kulkarni, Cane Sugar Manufacture, The sugar technologists association of India, New Delhi, 2002-03.

[2] A Jha, "India's sugar policy and world sugar economy" in proc. FAO International sugar conference, Fiji, August 2012.

[3] Indian Sugar Mills Association (ISMA), 2010, "Important Events" (online) available at: http://www.indiansugar.com/EventDetails

[4] S. Ahmed, Indian sugar industry, Centre for management studies, Jamia Millia Islamia, New Delhi, India, Unpublished.

[5] Sugar Knowledge International Ltd., "How sugar is made", (online) available at: http://www.sucrose.com/learn.html.

[6] D.J Tayfield, P.W Rein and S.R Proome, "The application of a microprocessor based system for automatic pan boiling control", Proc. The South African Sugar Technologists Association Conf; pp 56-62, June 1980.

[7] C.R Murry, "The Pressure Required to Feed Cane Mills". International Sugar Journal, 62, p. 346-349, 1960-61.

[8] T. Ozkocak and G.C Goodwin, "A Nonlinear Modeling Approach to The Sugar Cane Crushing Process". IEEE conference on Decision and Control, Florida, USAI.S.J., pp. 3144-3149, 1998.

[9] T. Ozkocak, M. Fu and G.C Goodwin, "Maceration control of a sugar cane crushing mill", Proc. American Control Conf; pp 2255-259, June 2000.

[10] Misra, Y., Digital System Design using VHDL, Dhanpatrai \& sons (P) Ltd., India, 2006.

[11] Bhasker, J., A VHDL Primer, Revised Edition PrenticeHall, 1992.

[12] Brown, S., Vranesic, Z., Fundamentals of Digital Logic with VHDL Design, McGraw-Hill, 2000.

[13] T Mitsuishi, N Endou and Y Sidhama, "The concept of fuzzy set and membership function and basic properties of fuzzy set operation" Journal of formalized mathematics, pp 1-6, Volume 12, 2003.

[14] Mathworks, "Fuzzy Logic Toolbox User's Guide ", Mathworks, Inc., 2010.

[15] R.M. Hilloowala and A.M. Sharaf, "A rule-based fuzzy logic controller for a PWM inverter in a standalone wind energy conversion scheme", in Industry Applications, IEEE Transactions, pp. 57-65, January/February 1996.

[16] L.Reznik, Fuzzy Controllers, Newnes-ButterworthHeinemann, Oxford-Boston, 1997, ISBN 0-7506-3429-4

[17] B Mahdad, T Bouktir and K Srairi, "Dynamic compensation of reactive energy usinf fuzzy controller" Leonardo Electronic Journal of practice and technologies, pp 1-16, Issue 7, July-December, 2005.

\section{Authors' Profiles}

Yogesh Misra received B.E (Electronics) from Marathwada University, Aurangabad, India in 1993, M.E (Electronics and Communication) from Maharishi Dayanand University, Rohtak, India in 2008 and pursuing $\mathrm{PhD}$ from Mewar University, Chittorgarh, India.

$\mathrm{He}$ is currently working as Assistant Professor at Mody University of Science \& Technology, Laxmangarh, India. He has worked in U V Instruments (P) Ltd, a sugar mill automation company for many years. He has authored a book titled Digital System Design using VHDL, New Delhi, Dhanpat Rai \& Co. (Pvt.) Ltd., 2006. His research interest includes VLSI CAD, VLSI embedded computing and soft computing.

Mr. Misra is life member of Indian Society of Technical Education. 
Prof. (Dr.) H R Kamath received B.E (Electrical and Electronics) from Mysore University, India in 1989, M. Tech (Power and Energy Systems) from NITK Suratkal in 1996 and $\mathrm{PhD}$ from Manipal University, India in 2008.

$\mathrm{He}$ is currently working as Director at Malwa Institute of Technology, Indore, India. His area of interest includes Distributed Power Generation/Renewable Energy Solar \& Hybrid Systems.

Dr. Kamath is life member of Indian Society of Technical Education, Indian Society of Lightning Engineers, System Society of India and Institute of Engineers.

How to cite this paper: Yogesh Misra, H R Kamath,"Design Algorithm and Performance Analysis of Conventional and Fuzzy Controller for Maintaining the Cane Level during Sugar Making Process", International Journal of Intelligent Systems and Applications (IJISA), vol.7, no.1, pp.80-93, 2015. DOI: 10.5815/ijisa.2015.01.08 